STUDIA NORWIDIANA 38:2020

DOI: https://doi.org/10.18290/sn.2038-13

RENATA GADAMSKA-SERAFIN

NORWID I EDMUND CHOJECKI-PODRÓŻNIK

W gronie znajomych Norwida poczesne miejsce przypadło, i to już w latach warszawskich (a później także w okresie berlińskim, włoskim i wreszcie paryskim), Edmundowi Franciszkowi Maurycemu Chojeckiemu (1822-1899), znanemu później pod francuskim pseudonimem Charles Edmond.

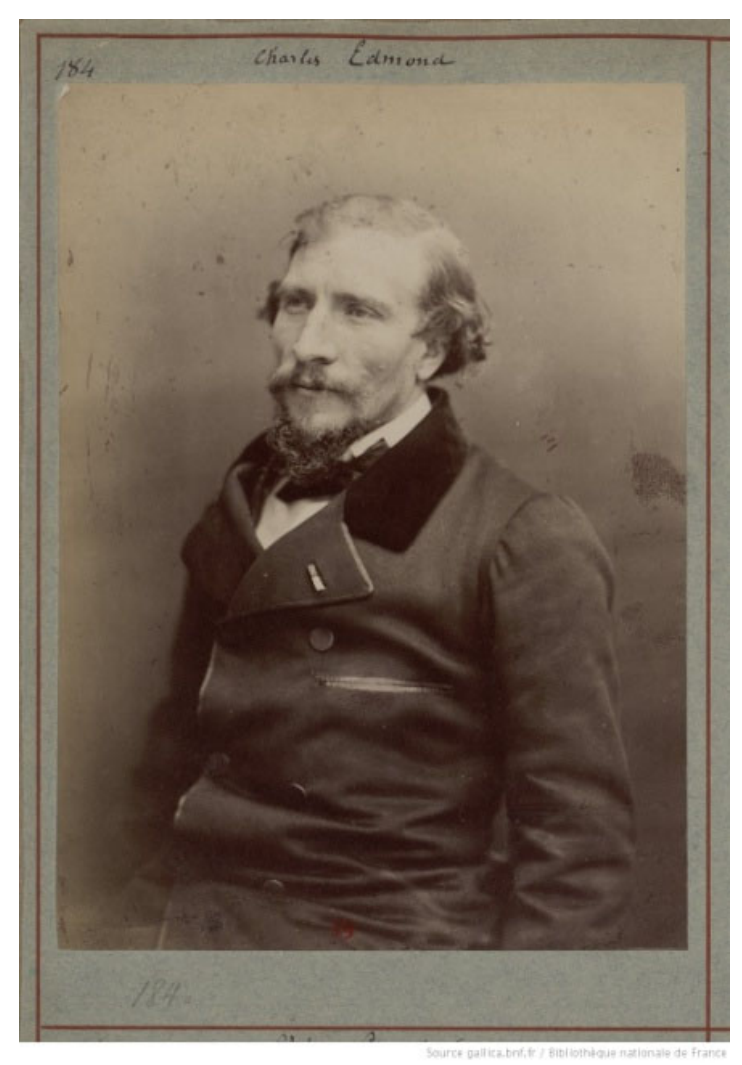

Fot. 1. Charles Edmond 
Była to osobowość intrygująca, wielowymiarowa, realizująca się na wielu polach: dwujęzyczny pisarz i poeta, dziennikarz, publicysta (choć bez wyższego wykształcenia $^{1}$ ), thumacz polsko-francuski (przełożył m.in. Rękopis znaleziony w Saragossie Jana Potockiego, Lipsk 1847), podróżnik, bibliotekarz, działacz polityczny, słowem - człowiek o niespożytej energii, rozległych zainteresowaniach i sporym dorobku literackim (w większości francuskojęzycznym), do tej pory nie do końca odkrytym przez rodaków (podstawowym mankamentem jest brak thumaczenia francuskiej sześciotomowej biografii pisarza spisanej przez jego „późnego wnuka” - Emmanuela Desurvire'a oraz jakiejkolwiek polskiej monografii twórczości Chojeckiego ${ }^{2}$ ).

${ }^{1}$ „Młody Chojecki nie zdecydował się na studia. Późniejszy jego biograf krewniak Artur napisał nie bez racji, że 'brak wyższych studiów i dyscypliny naukowej odbił się ujemnie na działalności politycznej i literackiej’. Studia były kosztowne, a i kontakt z życiem był utrudniony dyscypliną uczenia i kształcenia się. Chojecki - romantyk z krwi i kości - czuł potrzebę pisania, zabierania głosu w sprawach aktualnych i ważkich". B. PiotrowsKi, Edmunda Chojeckiego wyprawa na Islandię w 1856 r. [seria „Materiały o Islandii”, z. 53], Warszawa 1982, s. 3.

Mowa o biogramie E. Chojeckiego pióra Artura Chojeckiego (Chojecki Edmund), zamieszczonym w Polskim Słowniku Biograficznym, t. III, red. J. Brożek, F. Chwalczewski, Kraków 1937, s. 391-392.

${ }^{2}$ Autor wspomnianego wyżej biogramu pisarza w Polskim Słowniku Biograficznym Artur Chojecki (wnuk Artura Chojeckiego - brata Edmunda), informował o spoczywającej w rękopisie w jego papierach rodzinnych monografii autorstwa Marii Chojeckiej (córki Edmunda), Próba monografii E. Ch. (rękopis). Zob. A. CHOJECKI, Chojecki Edmund, s. 392.

W latach sześćdziesiątych i siedemdziesiątych XX wieku kilka szkiców poświęcił Chojeckiemu Z. Markiewicz, Charles Edmond - voyageur et comparatiste oublié, [w:] Études de littérature étrangère et comparée. Connaissance de l'étranger, Paris 1964, s. 292-300; Les relations de Charles Edmond avec Herzen et les émigrés (1849-1867), „Annali dell'Istituto Universitario Orientale. Sezione Slava" 7(1964); La servitude sans grandeur d'un écrivain bilingue (Ch. Edmond Chojecki), [w:] Actes du VIè Congrès de l'Association Internationale de Littérature Comparée, La Hague-Paris 1966; Charles Edmond Chojecki collaborateur de Sainte-Beuve, [w:] Mélanges de Littérature Comparée et de Philologie, Warszawa 1967, s. 337-343; Charles Edmond Chojecki collaborateur de Sainte-Beuve, [w:] Mélanges de littérature comparée et de philologie offerts à Mieczyslaw Brahmer, Warszawa 1967, s. $337-$ 343; Charles Edmond Chojecki intermédiare entre le monde slave et la France, „Canadian Slavonic Papers" 9(1967), nr 1. s. 122-130; Charles Edmond Chojecki et son activité dans le camp des démocrates (1847- 1899), „Acta Poloniae Historica” 37(1978), s. 163-174. Markiewicz wydał także korespondencję Chojeckiego i G. Flauberta: Flaubert et Charles Edmond, leur correspondance (1857-1877), Paris 1967.

W wieku XX ukazał się również wspominany wyżej szkic B. Piotrowskiego Edmunda Chojeckiego wyprawa na Islandię w 1856 r., niedawno zaś artykuł K. WESTERMARK, Między wyobrażonym a realnym końcem świata. Islandia w ,Voyage dans les mers du nord” Edmun- 
Urodzony w Wiskach na Podlasiu w roku balladowego debiutu Mickiewicza (a więc rok młodszy od Norwida), Chojecki pobierał nauki w dawnym Liceum Warszawskim, którego dyrektorem był wówczas wybitny leksykograf i językoznawca Samuel Bogumił Linde (języka francuskiego zaś uczył ojciec Fryderyka Chopina - Mikołaj). Szkolnymi kolegami Edmunda byli Felicjan Faleński i Wacław Szymanowski ${ }^{3}$. W latach czterdziestych zawiązała się także jego przyjaźń z Cyprianem Norwidem.

$\mathrm{W}$ tomie pierwszym sześciotomowej biografii Chojeckiego spisanej przez Desurvire'a, obejmującym lata 1822-1856, nazwisko Norwida pojawia się tylko dwa razy, we wprowadzeniu i w rozdziale poświęconym życiu literackiemu oraz politycznemu Warszawy w pierwszej połowie XIX wieku ${ }^{4}$. Podobnie jest w pozostałych tomach ${ }^{5}$. Na niewiele wzmianek o autorze Vade-mecum natrafimy też

da Chojeckiego, [w:] Romantycy na krańcach świata. Podróże egzotyczne i peregrynacje wewnętrzne, red. E. Modzelewska i P. Sobol, Kraków 2015, s. 63-76.

Braki polskiego literaturoznawstwa nadrobił w XXI wieku francuski potomek pisarza Emmanuel Desurvire, wybitny fizyk francuski. W latach 2013-2014 ukazała się we Francji jego sześciotomowa biografia Edmunda, zatytułowana Charles Edmond Chojecki. Patriote polonais, explorateur, soldat, poète, dramaturge, romansier, journaliste, bibliothécaire... Saint-Escobille 2011-2014. Jej fragmenty dostępne są online na stronach: https://books.google.pl/books?id=V0BJDwAAQBAJ\&printsec $=$ frontcover\&hl $=$ pl\&source $=$ gbs_ViewAPI\& redir_esc $=\mathrm{y} \# \mathrm{v}=$ onepage \&q\&f=false (dostęp: 20.11.2018) bądź https://www.amazon.com/ Charles-Edmond-Chojecki-I-French/dp/1470977931 (dostęp: 20.11.2018). Zob. też J. CHAPLAIN, [Nota o książce:] Emmanuel Desurvire „,Karol Edmund Chojecki, polski patriota, odkrywca, żotnierz, dramaturg, powieściopisarz, publicysta, bibliotekarz...”. „Studia Polonistyczne" 49(2014), s. 223-225.

E. Desurvire jest także autorem jednotomowej biografii Chojeckiego Charles Edmond Chojecki. L'Oeuvre et la Vie, Saint-Escobille 2014. Wydał on również zbiór zachowanej korespondencji Edmunda Chojeckiego: Ch. EDMOND, Correspondance, oprac. E. Desurvire, Paris 2014. Zob. też E. DESURVIRE, Francuska twórczość teatralna Charles'a Edmonda, przeł. P. Śniedziewski, „Prace Polonistyczne” 70(2015), s. 51-80 oraz TENŻE, La comtesse Laura Czosnowska ou le malheureux destin d'une lionne, „Studia Norwidiana” 32(2014), s. 207-231.

${ }^{3}$ Zob. A. CHOJECKI, Chojecki Edmund, s. 391.

${ }^{4}$ Zob. E. Desurvire, Charles Edmond Chojecki. Patriote polonais, t. I, s. 13 i 34.

Jest rzeczą zrozumiałą, że w monografii spisanej we Francji, przez francuskojęzycznego autora ukazane jest szeroko (i przede wszystkim) tło francuskie, podczas gdy kontekst polski jest znacznie słabiej reprezentowany i rozeznany. Desurvire odnotowuje oczywiście fakt, iż Chojecki pozostawał „l'ami intime de Chopine et de Norwid” (E. Desurvire, Charles Edmond Chojecki. Patriote polonais, t. IV, s. 14), jednak nie omawia szczegółowo dziejów jego relacji z Norwidem.

${ }^{5} \mathrm{~W}$ tomie drugim (obejmującym lata 1857-1872) nie ma, o dziwo, żadnej wzmianki o Norwidzie, w tomie trzecim (lata 1873-1899) jego nazwisko pojawia się cztery razy (s. 333, 334, 363 i 438). W tomach IV-VI poeta jest wspominany jeszcze kilkakrotnie. 
w jednotomowej biografii Charles Edmond Chojecki. L'Oeuvre et la Vie ${ }^{6}$. Ta skromna statystyka mogłaby sugerować czytelnikom epizodyczny charakter owej znajomości, tymczasem trwała ona niemal przez całe życie Norwida (przynajmniej do lat 70), niewątpliwie była też ważna dla obu stron ${ }^{7}$. Jej świadectwa epistolograficzne są rzeczywiście bardzo nieliczne; w zbiorze korespondencji Chojeckiego zachowały się zaledwie trzy listy do Norwida (z Egiptu z 25 października 1850 i dwa paryskie: z 3 maja 1869 r. i z 1 grudnia 1876 r. ${ }^{8}$ ), przepadła zaś cała korespondencja Norwidowska skierowana do Chojeckiego 9 . Edmund był jednak kilkakrotnie wspominany przez poetę w listach adresowanych do innych odbiorców, głównie do Marii Trębickiej i Emmy Herwegh (zob. Indeks osób, PWsz X, 419).

W Warszawie Cyprian i Edmund publikowali na łamach „Przeglądu Warszawskiego" i „Biblioteki Warszawskiej”, obaj byli też ulubieńcami salonów ${ }^{10}$; spotykali się m.in. na wieczorach u pisarki Katarzyny Lewockiej, u której skupiało się środowisko „Przeglądu” i „Gazety Warszawskiej”; u Niny Łuszczewskiej, u kasztelana Jana Nepomucena Bielińskiego, w kawiarni Grassowa na Trębackiej ${ }^{11}$. Przyjaźnili się z Władysławem Wężykiem, którego niedawna podróż „po starożytnym świecie” wyzwoliła w nich egiptologiczną pasję i marzenie o odwiedzeniu kraju faraonów. Chojecki miał zrealizować ten orientalny projekt na wygnaniu, w niedalekiej przyszłości, Norwid - oblec go jedynie w kształt literacki, pisząc w latach siedemdziesiątych Kleopatrę i Cezara.

\footnotetext{
${ }^{6}$ Tu nazwisko Norwida pojawia się również kilka razy (dokładnie pięć).

${ }^{7}$ Desurvire zdawał sobie oczywiście sprawę z wagi tej relacji. Pisząc o warszawskim kręgu przyjaciół Edmunda puentował: „Żeby skompletować koło [znajomych Chojeckiego z Warszawy - R.G.-S.] wspomnijmy w końcu Cypriana Norwida, zaledwie rok starszego od Edmunda, urzeczonego przez piękną hrabinę Kalergis, i oczywiście przyjaciela jej zaufanej Marii [Trębickiej - R.G.-S.], kuzynki Edmunda. Norwid stanie się jedną z największych figur poezji polskiej, i będzie to, dla niego, który nazywał Edmunda Chojeckiego 'mój brat', przyjaźń życia”, E. Desurvir, Charles Edmond Chojecki. L'Oeuvre et la Vie, s. 25.

Oczywiście lata warszawskie, okres gorącej przyjaźni, były czasem najintensywniejszych kontaktów Norwida z Chojeckim. Po powrocie Cypriana z Ameryki dawni przyjaciele szli już zupełnie oddzielnymi drogami i kontakty mieli rzadkie. Możemy się domyślać, że wyjątkowy był czas Wystawy Powszechnej w 1867 r., kiedy znów mogli się częściej spotykać.

${ }^{8}$ Ch. Edmond, Correspondance, s. 189 (list nr 442).

${ }^{9} \mathrm{Z}$ korespondencji wynika, że zaginęły co najmniej cztery listy Norwida do Chojeckiego (zob. Listy zaginione PWsz X, 294, 296, 304, 307). Z pewnością było ich jednak więcej.

${ }^{10}$ Ich bywanie w salonach warszawskich wspomina m.in. E. SKRODZKI, Wieczory piatkowe i inne gawędy, wstęp i oprac. M. Opałek, Warszawa 1962, s. 149.

${ }^{11}$ Zob. Z. Trojanowiczowa, Z. DAMBEK, Kalendarz życia i twórczości Cypriana Norwi$d a$, t. I: 1821-1860, Poznań 2007, s. 64-82.
} 
Ciekawych szczegółów na temat warszawskiej przyjaźni Norwida z Chojeckim dostarczają listy Wojciecha Potockiego adresowane do Andrzeja Edwarda Koźmiana $^{12}$. Ich autor wspomina m.in. to, jak Cyprian troskliwie opiekował się poturbowanym Edmundem, którego „konie poniosły” („Norwid jest szarą siostrą, aniołem opiekuńczym przy jego łóżku"13).

Młodzieńcy byli jednak bardzo różni. Chojecki cieszył się w Warszawie opinią ,salonowego dowcipnisia, kieszonkowego poety, znakomitego pod każdym względem kuglarza, jednego z najwcześniejszych na naszej ziemi blagierów”"14.

Werwa poetyczna, olbrzymia pamięć, zdolność do wszystkiego, łatwość w wysławianiu się i talent improwizatorski uczyniły z niego ulubieńca salonów. Wyrywano go sobie, a sam kwiat towarzystwa schodził się thumnie do szczęśliwej gospodyni domu, u której miał improwizować Chojecki ${ }^{15}$.

Odmienność charakterów i życiowych postaw tych świetnie zapowiadających się literatów celnie uchwycił w liście do Andrzeja Edwarda Koźmiana Wojciech Potocki:

Ci dwaj młodzi ludzie wiele obiecują [Norwid i Chojecki], ale Chojecki próżniak, a Norwid ciągle pracuje i w starych książkach siedzi ${ }^{16}$;

Chojecki - dziecię pieszczone miłości i szczęścia; jego poezja inny ma charakter, ale kochają się z Norwidem jak bliźnięta. Mili i kochani obydwa, są te dwa czyste nieskażone kryształy w świecie warszawskim. Ale Chojecki - piękny, świetny i odurzający - zawraca głowy, a Norwid - cichy, ponury i milczący - nie ściąga na siebie oczów, i wtedy dopiero ujrzą, kiedy urósłszy w olbrzyma, zgniecie, jak Byron, jednym stąpieniem, wijące się mu koło nóg robactwo i gady ${ }^{17}$.

${ }^{12}$ Dostrzegły to autorki kalendarium norwidowskiego. Zob. Z. TroJANOwiczowA, Z. DAMBEK. Kalendarz, s. 64, 67, 69, 78, 107.

${ }^{13}$ List W. Potockiego do A. E. Koźmiana z 20-22 lipca 1841. Rkps Bibl. Nauk. PAU i PAN 2039, k. 178-179. Cyt. za: Z. TrojanowiczowA, Z. DAMBEK, Kalendarz, s. 87.

${ }^{14}$ F. FALEŃSKI, Wspomnienia z mojego życia, oprac. J. Rudnicka, „Archiwum Literackie. Miscellanea z pogranicza XIX i XX wieku” 1964, s. 37.

${ }^{15}$ E. SKRODZKI, Wieczory piątkowe, s. 150.

${ }^{16}$ List W. Potockiego do A. E. Koźmiana (bez daty [1841]). Cyt. za: J.W. GomULICKI, Nieznane relacje o Norwidzie, „Stolica” 1962, nr 23, s. 19.

${ }^{17}$ List W. Potockiego do A. E. Koźmiana z 25 marca 1841. Cyt. za: J.W. GomULICKI, O nieznanym dramacie Norwida, „Pamiętnik Teatralny” 1961, z. 2, s. 203. 
Z czasem sympatia Potockiego wyraźnie przechyliła się na stronę Norwida:

Dawno tyle kogo nie kochałem, dawno tyle godnym kochania nie znałem, jak Norwid. Biedny on, między ludźmi jest jak gołąb pośród sępów, jastrzębi i krogulców ${ }^{18}$.

Rzeczywiście, w przeciwieństwie do Norwida Chojecki już w młodości odznaczał się pewnością siebie, przebojowością, ekstrawersją, ogromną zaradnością życiową, pragmatyzmem i elastycznością, zdolnością adaptowania się do nowych warunków, chwytania wszelkich nadarzających się w życiu okazji i łatwością nawiązywania przydatnych znajomości (w latach warszawskich jego protektorami byli Franciszek Ksawery Branicki, Roger Raczyński, ks. Jadwiga Lubomirska). Na emigracji miał zaprzyjaźnić się z wieloma wybitnymi osobistościami swoich czasów - nie zabrakło wśród nich pisarzy, myślicieli, uczonych, członków akademii i prestiżowych towarzystw naukowych, ekonomistów, polityków i dyplomatów, wpływowych arystokratów ${ }^{19}$, a nawet głów koronowanych, jak vice-król Egiptu Ismael Pasza czy omal niekoronowany na cesarza ks. Napoleon „Plon-Plon”. Rozległe znajomości w kręgach elit świata literackiego i politycznego ułatwiały Edmundowi realizację ambitnych przedsięwzięć i wybawiały go niejednokrotnie z opresji.

Owa różność charakterów Cypriana i Edmunda, dostrzeżona przez Potockiego już w Warszawie, miała przełożyć się w przyszłości na radykalną odmienność ich losów: powodzenie, a nawet zawrotną karierę Chojeckiego oraz postępującą izolację i życiową klęskę Norwida.

Przyjaźń Norwida z Chojeckim była relacją wielowątkową, wieloaspektową (ważny jest w niej na przykład wątek polityczny, związany z działalnością Edmunda w kołach lewicowych i wizytami w skupiającym zaangażowanych w nie ludzi salonie Emmy Herwegh; postać Marii Trębickiej, blisko spokrewnionej

\footnotetext{
${ }^{18}$ List W. Potockiego do A. E. Koźmiana z lipca 1841. Rkps Bibl. Nauk. PAU i PAN 2039, k. 143 r. i v. Cyt. za: Z. TrojanowiczowA, Z. DAmBeK, Kalendarz, s. 90.

Chojecki wydał się autorowi listu nazbyt dystyngowany, nadto nie tak prostolinijny i kryształowy jak Norwid. Po przyjeździe do Warszawy w lipcu 1841 r., Wojciech Potocki pisał z Hotelu Saskiego do tegoż Koźmiana: „raniuteńko przybiegł poczciwy Norwid, a wkrótce potem raczył łaskawie przybyć wyperfumowany i wyświeżony jak laleczka Chojecki”. List W. Potockiego do A. E. Koźmiana, Rkps Bibl. Nauk. PAU i PAN 2039, k. 164. Cyt. za: Z. Trojanowiczowa, Z. DAMBEK, Kalendarz, s. 86.

${ }^{19} \mathrm{~W}$ biografii (i listach) Chojeckiego przewijają się np. takie nazwiska, jak: A. Mickiewicz, J. Słowacki, C. Norwid, G. Flaubert, T. Gautier, bracia J. i E. de Goncourt, G. Sand, A. Herzen, I. Turgieniew, Ch.-A. Sainte-Beuve, F. Liszt, P. J. Proudhon, August Mariette (wybitny archeolog i egiptolog francuski ) $\mathrm{i}$ inne.
} 
z Chojeckim ${ }^{20}$; historia Laury Czosnowskiej, która być może zakończyła życie w tym samym co Norwid Domu św. Kazimierza ${ }^{21}$ i inne). Nie sposób ukazać całokształt tej znajomości w jednym, krótkim szkicu, dlatego konieczne jest dokonanie wyboru jednego zagadnienia.

Historia literatury polskiej i francuskiej ocaliła pamięć o Chojeckim poecie, pisarzu (w tym dramatopisarzu), ale był on również jednym z ważniejszych podróżników polskich XIX wieku. Przedmiotem niniejszej publikacji staną się właśnie doświadczenia podróżnicze Edmunda Chojeckiego, które rozbudzały Norwidowskie pragnienie poznania świata (zwłaszcza Wschodu) - marzenie, by choć „trochę świata nieznanego wziąć w płuca i w wyobraźnię” (PWsz VIII, $387)^{22}$. W zachowanych listach Norwida (które stanowią, jak szacował Gomulicki, zaledwie około $50 \%$ całości) brak wprawdzie jakiejkolwiek wzmianki na temat lektury podróżniczych dzieł przyjaciela ${ }^{23}$, jednak trudno sobie wyobrazić, by wojaże Chojeckiego nie zainteresowały i nie inspirowały jego mniej fortunnego kolegi po piórze, tym bardziej, że Norwid czynił przecież starania o wspólny z Chojeckim udział w wyprawie do mórz północnych (będzie o tym jeszcze mowa w dalszej części niniejszej publikacji).

\section{CZĘŚĆ I. KRYM}

W roku 1843 Chojecki słuchał wykładów Schellinga w Berlinie ${ }^{24}$, w tym samym też roku hrabia Franciszek Ksawery Branicki ${ }^{25}$ (znany również Norwi-

\footnotetext{
${ }^{20}$ Zob. E. Desurvire, Charles Edmond Chojecki. L'Oeuvre et la Vie, s. 25.

${ }^{21}$ Chojecki miał romans z L. Czosnowską. Jego owocem była nieślubna córka pisarza Maria Chojecka. Zob. E. DESURVIRE, La comtesse Laura Czosnowska ou le malheureux destin d'une lionne.

${ }^{22}$ W roku 1859 w liście do kuzyna M. Kleczkowskiego Norwid pisał: „Byłoby to wszelako i dla pisarza, i dla sztukmistrza użyteczne rzucić okiem na nieznane barwy i elementów nieznanych doświadczyć - mogłoby to skompletować moje skarby zaczarowane, przy których goły zawsze jestem" (DW XI, 336).

${ }^{23}$ Wiemy natomiast, że Norwid rozczytywał się w młodości w relacjach egipskich W. Wężyka.

${ }^{24}$ Zob. E. DeSURVIRE, Francuska twórczość teatralna Charles'a Edmonda, s. 52.

Chojecki rozpoczął berlińskie studia już wcześniej (jesień 1841-wiosna 1842), a do Berlina pojechał niejako „zamiast” Norwida (którego chciał wysłać na studia filozoficzne do Berlina na początku lat czterdziestych August Cieszkowski). Zob. E. LIJEWSKA, $O$ dwóch Quidamach. Norwid - Kierkegaard, [w:] ,,Quidam”. Studia o poemacie, red. P. Chlebowski, Lublin 2011, s. 256-257 oraz TAŻ, Profetyczny ironista na przełomie epok, „Roczniki Kulturoznawcze" 7(2016), nr 3, s. 85 i 87.
} 
dowi $^{26}$ ) - szwagier Zygmunta Krasińskiego (brat Elżbiety „Elizy” Krasińskiej i Zofii Odeschalchi), wówczas oficer armii carskiej armii na Kaukazie i adiutant gen. Paskiewicza ${ }^{27}$, zabrał Chojeckiego w pierwszą egzotyczną, trwającą ponad pół roku podróż na Krym (od sierpnia 1843 do marca 1844) 2 $^{28}$, gdzie rodzina Branickich miała posiadłości i krewnych ${ }^{29}$. Owocem literackim orientalnej wyprawy sponsorowanej przez hrabiego Branickiego były ilustrowane Wspomnienia z podróży po Krymie, wydane nakładem autora w Warszawie w roku $1845^{30}$.

Norwid, który spotkał się z Chojeckim w roku 1845 w Dreźnie, w drodze do Berlina $^{31}$, zapewne wysłuchał jego opowieści o krymskiej podróży i świeżym

\footnotetext{
${ }^{25}$ Fr. Ksawery był wnukiem Ksawerego Branickiego, jednego z przywódców konfederacji targowickiej. Za pośrednictwem Branickiego Chojecki mógł poznać rodzinę włoskich książąt Odescalchi (siostra Fr. Ksawerego, Zofia, była żoną ks. Liwiusza III Odescalchi) i rodzinę Bonapartów.

Patronat lewicującego hrabiego Branickiego miał zaważyć na poglądach politycznych Chojeckiego - przyszłego proudhonisty i sekretarza redakcji Mickiewiczowskiej „Trybuny Ludów" (głównym sponsorem gazety był właśnie Branicki). Przed lewicowymi poglądami swego szwagra i jego otoczenia przestrzegał Norwida Z. Krasiński. Zob. Z. TrojANOwICZOWA, Z. DAMBEK, Kalendarz, s. 343.

${ }^{26}$ Autorki kalendarza norwidowskiego przypuszczają, iż to właśnie za pośrednictwem Chojeckiego Norwid poznał w Warszawie Branickiego. Zob. Z. TrojANOwICZOWA, Z. DAMBEK, Kalendarz, s. 55. O relacjach Norwida z hr. F.K. Branickim zob. A. CZARTKOwsKI, Cyprian Norwid a Ksawery Branicki, „Kurier Warszawski” 113(1933), nr 140, s. 4-6 oraz Ł. NiEwCZAS, Norwid - Branicki - Matejko - Berezowski, „Studia Norwidiana” 34: 2016, S. 125-138.

Brat Ksawerego Branickiego - Aleksander był także podróżnikiem. Interesował się botaniką i współpracował z A. Wagą, finansował też badania B. Dybowskiego. Zob. Z. TrojANoWICZOWA, Z. DAMBEK, Kalendarz, s. 55.

${ }^{27}$ Branicki prawdopodobnie czynił już wówczas starania o dymisję z armii rosyjskiej. W roku 1844 opuścił bowiem Rosję, korzystając z nieobecności cara (przebywającego wówczas w Londynie), i wyjechał na emigrację pod pretekstem poratowania zdrowia we Włoszech.

${ }^{28}$ Zob. E. Desurvire, En Crimée avec le comte Branicki, [w:] E. Desurvire, Charles Edmond Chojecki. Patriote polonais, t. I, s. 35-40 oraz E. DESURVIRE, Francuska twórczość teatralna Charles'a Edmonda, s. 52.

${ }^{29}$ Braniccy zawdzięczali te posiadłości swemu zhańbionemu, cynicznemu dziadowitargowiczaninowi, który po małżeństwie z Aleksandrą Engelhardt (prawdopodobnie córką Katarzyny II i Potiomkina) otrzymał je od carycy jako gratyfikację za polityczne przysługi (dostał też olbrzymie połacie ziemi na Kijowszczyźnie, z centrum w Białej Cerkwi, i na Wołyniu). Córka Aleksandry i hetmana Fr. Ksawerego - targowiczanina, Elżbieta, została żoną Michaiła Woroncowa - carskiego namiestnika i wicekróla Kaukazu. Woroncowowie mieli w Ałupce na Krymie piękny pałac.

${ }^{30}$ Zob. E. CHOJECKI, Wspomnienia z podróży po Krymie, Warszawa 1845.

${ }^{31}$ Zob. Z. Trojanowiczowa, Z. DAMBEK, Kalendarz, s. 184.
} 
przedsięwzięciu wydawniczym. Wymiana listów trwała zresztą także podczas pobytu Norwida w Berlinie, przyjaciele przekazywali sobie też pozdrowienia za pośrednictwem kuzynki Edmunda - Marii Trębickiej. W adresowanej do niej listach Chojecki dawał niejednokrotnie wyrazy sympatii, przywiązania i szczerego podziwu dla Norwida: „Czuję potrzebę wzmocnienia się w obecności tego ewangelicznego charakteru” ${ }^{32}$; „Z prawdziwą radością myślę o chwili, w której go zobaczę $[\ldots], 33$.

Obszerne, bo ponadtrzystustronicowe, krymskie dzieło podróżnicze Chojeckiego nie było zwykłą relacją z podróży, obfitującą w detale krajoznawcze i historyczne, choć z pewnością mogłoby posłużyć (nawet i dziś jeszcze) za ciekawy, wyczerpujący przewodnik turystyczny po Krymie (a nawet podróż taką... zastąpić). Ma ono zróżnicowaną, nieco sylwiczną strukturę genologiczną; jest to tyleż relacja z podróży i przewodnik wskazujący szczegółowo trasy zwiedzania, co dość ambitnie pomyślane dzieło historyczne. Nietrudno dostrzec we Wspomnieniach także talent beletrystyczny - pióro literata i dziennikarza: sporo tu sfabularyzowanych opowieści, mitów, legend, podań, wschodnich romansów oraz rozmaitych dygresji współczesnych.

Oczywiście Chojecki nie był pierwszym twórcą, który zabierał polskich czytelników do starożytnej ziemi Greków, Scytów i Mongołów; wyobrażenia odbiorców na temat tej orientalnej krainy zostały trwale ukształtowane przez Sonety krymskie (te wywołały zarazem spory „popyt” na opisy podróżnicze Krymu Chojecki bardzo umiejętnie wykorzystał więc „koniunkturę” na rynku czytelniczym). Młody autor (notabene słuchacz Mickiewiczowskich wykładów w Collège de France) postanowił jednak przekornie zaprzeczyć konwencji wyznaczonej przez krymskie arcydzieło wieszcza. Kierowała nim skłonność do weryfikacji, urealniania i demitologizacji, do nicowania romantycznych stereotypów (podważał na przykład romantyczny mit Ukrainy - mit stepu, który, jak twierdził, zastąpiły „klasyczne ruiny i strumyki” ${ }^{34} \mathrm{z}$ nikłą korzyścią dla literatury). Mickiewiczowski Krym bywał we Wspomnieniach odczarowywany, a natura zdecydowanie zmieniała skalę; niebosiężny i nieosiągalny „gór padyszach” Czatyrdah został przez Chojeckiego zdobyty, a relacja zawierała dokładny opis ścieżki wiodącej na szczyt, zmieniających się pięter roślinności, a nawet informacje o budowie geologicznej góry ${ }^{35}$.

\footnotetext{
${ }^{32}$ J. CZARnOMORSKA, Norwidiana $w$ korespondencji Marii Trębickiej, „Studia Norwidiana" 9-10: 1991-1992, s. 143.

${ }^{33}$ Tamże, s. 144.

${ }^{34}$ E. CHOJECKI, Wspomnienia z podróży po Krymie, s. 12.

${ }^{35}$ Zob. tamże, s. 239.
} 
W konkluzji Wspomnień rysowała się też perspektywa dalsza, równie pociągająca: góry Kaukazu, Persja Saadiego, Hafiza i Ferdousiego oraz dorzecze Eufratu i Tygrysu, gdzie „dziejopisowie raj ziemski umieszczają"36. Tak oto marzenie o odkryciu Orientu zaczęło kiełkować w duszy Chojeckiego, a poprzez niego - także i Norwida.

Przyjaciele utrzymywali stały kontakt podczas pobytu Cypriana we Włoszech w latach czterdziestych, o czym świadczą relacje Ludwika Orpiszewskiego przesyłane Adamowi Czartoryskiemu ${ }^{37}$ oraz korespondencja Norwida z Józefem Bohdanem Zaleskim, który na początku 1848 r. przekazał Chojeckiemu rękopis Norwidowskiej Wandy, w celu jej opublikowania (do czego jednak nie doszło, Chojecki oddał bowiem utwór do druku w lutym 1848 r. i rękopis zaginął podczas rewolucji lutowej). Ścisłe relacje były podtrzymywane także w Paryżu, gdzie Chojecki został sekretarzem „Trybuny Ludów”, współpracownikiem „Revue Independente” i socjalistycznej „La Voix du Peuple” Proudhona. W życiu Edmunda rozpoczął się okres politycznego radykalizmu.

Norwid zawdzięczał Chojeckiemu znajomości z wieloma przedstawicielami paryskich elit. Prawdopodobnie to właśnie za jego pośrednictwem poznał w Paryżu Juliusza Słowackiego niedługo przed jego śmiercią ${ }^{38}$. Pod koniec lat czterdziestych Edmund wprowadził go także do salonu Emmy Herwegh ${ }^{39}$, której mąż był przywódcą nieudanego powstania badeńskiego w roku 1848, salonu ,odwiedzanego wówczas przez indywidualności mniej lub bardziej znane w tendencjach i pracach liberalnych" (List Norwida do A. Hercena, PWsz VIII, 200), m.in. przez Hercena, Turgieniewa, Bakunina, Orsiniego (przyszłego zamachowca na życie Napoleona III), ludzi związanych z Proudhonem, Mierosławskiego, Cieszkowskiego, Libelta i innych ${ }^{40}$. Chojecki posługiwał się już wówczas (od roku $1849^{41}$ ) francuską wersją nazwiska: Charles Edmond. Norwid wspominał go później z salonu Herweghów jako „elokwentnego Édouarda” (List do E. Herwegh, DW X, 441).

\footnotetext{
${ }^{36}$ Tamże, s. 313.

${ }^{37}$ Zob. Z. Trojanowiczowa, Z. DAMBeK, Kalendarz, s. 253.

${ }^{38}$ Chojecki opowiadał też prawdopodobnie Norwidowi o uratowaniu rękopisu wiersza Do autora psalmów, który Słowacki chciał spalić. Anegdotę tę przytacza Norwid w Lekcji VI O Juliuszu Stowackim (PWsz VI, 457). Zob. Z. TrojAnOwiCzOWA, E. LiJEWSKA, Kalendarz zycia i twórczości Cypriana Norwida, t. II: 1861-1883, s. 299-300.

${ }^{39}$ Zob. E.H. CARR, The Romantic Exiles: a Nineteenth Century Portrait Gallery, London 1933, s. 56, 119, 135.

Emma Herwegh została kolejną wspólną korespondentką obu przyjaciół.

${ }^{40}$ Zob. Z. TrojanowiczowA, Z. DAMBEK, Kalendarz, s. 354-355.

${ }^{41}$ Zob. A. CHOJECKI, Edmund Chojecki, s. 391.
} 
Na początku lat pięćdziesiątych drogi Chojeckiego i Norwida rozeszły się na jakiś czas. Pierwszy, za swą działalność polityczną został w roku 1850 nakazem policji wydalony z Francji. Wyjechał do Egiptu (za radą Victora Hugo ${ }^{42}$ ), by następnie, po wybuchu wojny krymskiej, wstąpić na ochotnika do armii Omara Paszy (później zwiedził jeszcze Włochy i Szwajcarię). Drugi, załamany odrzuceniem i niezrozumieniem, rzucił się w listopadzie 1852 r. do Ameryki. Spotkali się ponownie $\mathrm{w}$ Paryżu prawdopodobnie dopiero w roku 1855 (a może nawet jeszcze później) - Norwid wspominał w liście do Emmy Herwegh (z 1859 r.) z wielkim żalem, że Chojecki nie przyszedł nawet odwiedzić go po jego powrocie z Ameryki (Norwid wrócił pod koniec grudnia roku 1854):

[...] po powrocie z Ameryki bowiem dawny krąg znajomych Pani wydał mi się tak trudny do odnalezienia, szczególnie w sensie moralnym, że nie widuję już nawet Charlesa-Edmonda, mego przyjaciela $z$ lat młodości, bo nie przyszedł zobaczyć się ze mną... Prawie wszyscy ci panowie są dziś urzędowymi osobistościami, ja zaś nie zabiegam o protekcje, natomiast szczerość stosunków nierozerwalnie wiąże się z ich trwałością. (DW XI, 302)

Wszystko wskazuje więc na to, iż połowa lat pięćdziesiątych stanowiła moment zwrotny w historii znajomości Norwida i Chojeckiego. W tamtym czasie życiowe priorytety i ścieżki losu dawnych przyjaciół były już bardzo rozbieżne. Potwierdzeniem tego faktu stały się wydarzenia związane z wyprawą na Islandię.

\section{CZĘŚĆ II. PODRÓŻ DO MÓRZ PÓŁNOCNYCH}

Chojecki powrócił do Francji (z wygnania) w roku 1852. Zawdzięczał to wstawiennictwu kuzyna (stryjecznego brata) Napoleona III - księcia Napoleona „Plon-Plon” (1822-1891), którego poznał we Włoszech rok wcześniej i z którym połączyła go przyjaźń. W roku 1856 został jego osobistym sekretarzem i w tej roli wziął udział w morskiej ekspedycji księcia na Islandię i Grenlandię ${ }^{43}$ na

${ }^{42}$ Zob. E. DeSurvire, Charles Edmond Chojecki. L'Oeuvre et la Vie, s. 8.

${ }^{43}$ Zob. B. PIOTROWSKI, Edmunda Chojeckiego wyprawa na Islandie w 1856 r.; K. WeStermark, Między wyobrażonym a realnym końcem świata. Zob. też E. Desurvire, Charles Edmond Chojecki. Patriote polonais, t. I, s. 347-413.

Na krótko przed podróżą z księciem Napoleonem na Morze Północne, w czerwcu 1856 r., Charles Edmond poddał się operacji głowy. Zob. E. DeSURVIRE, Francuska twórczość teatralna Charles'a Edmonda, s. 55 (przypis 12). 
korwecie „Królowa Hortensja”. W trakcie wyprawy, trwającej od 15 czerwca do 6 września, prowadził dziennik podróży. Trasa wiodła przez wybrzeża szkockie, Islandię, Grenlandię, Szetlandy do krajów skandynawskich. Celem było rozpoznanie tego mało uczęszczanego przez Europejczyków obszaru świata, zbadanie jego wulkanów, lodowców i złóż (co miało zapewne i ukryte motywacje kolonialne).

W tym ciekawym przedsięwzięciu badawczym gorąco pragnął uczestniczyć także Norwid, który zgłosił swój akces jako artysta-rysownik, jego kandydatura (początkowo akceptowana) została jednak odrzucona. Oficjalnie powodem odmowy było zbyt późne zgłoszenie:

[Norwid] - pisał do Lenartowicza Józef Zaleski - miał jako rysownik odpłynąć z księciem Napoleonem do Szwecji, ale że mu tam ktoś buty uszył, a więc mu grzecznie odpisano, że szkoda, iż się wcześniej nie podał, bo teraz już wszystkie miejsca scjentyficzne zajęte, i tak nieborak na koszu osiadł (PWsz VIII, 530).

Poeta, mający wówczas za sobą epizod amerykański i od lat bezskutecznie starający się o jakiekolwiek zatrudnienie, które zapewniłoby mu choćby elementarną stabilizację ${ }^{44}$, przyjął to niepierwsze w swym życiu wykluczenie z głębokim smutkiem:

[...] odebrałem od księcia N[apoleona] list, w którym uprzejmie raczy on żałować, iż wcześniej o tym nie myśliłem - że nawet nie dwóch, ale jednego już tylko z przyjętych w Ekspedycji artystę zatrzymać będzie mógł, tak dalece mało jest miejsca materialnie (List C. Norwida do M. Pawlikowskiego, DW XI, 72).

W liście do Marii Trębickiej winą za fiasko swych starań obarczył Chojeckiego, pozostawiając jednak dla siebie szczegóły domniemanych intryg swego przyjaciela (a jej kuzyna!):

Zob. też M. JANION, Skald jako poeta romantyczny, [w:] Zwierciadła północy: zwiąki i paralele literatur polskiej i skandynawskiej, red. M. Janion, N. Åke Nilsson, A. Sobolewska, Warszawa 1991, t. I oraz J. KAMIONKA-STRASZAK, „Barbarzyński” heroizm i tkliwa melancholia. Literatura skandynawska w polskich almanachach dobry romantyzmu, [w:] Zwierciadła pótnocy. Związki i paralele literatur polskiej i skandynawskiej, t. I, s. 60-87.

${ }^{44} \mathrm{~W}$ tym właśnie czasie Norwid borykał się z ogromnymi problemami finansowymi. Pieniądze pożyczone od Mieczysława Pawlikowskiego oddawał w maleńkich ratach (był w stanie zwrócić jednorazowo zaledwie 30 franków), pożyczał też od niego ,uniform czarny na godzinę" (PWsz VIII, 262), nie miał bowiem żadnego wizytowego ubrania. 
Miałem w przeszłym miesiącu wyjechać do Bieguna-północnego, tam gdzie Franklin [Alfred Franklin - podróżnik angielski - R.G.-S.] ${ }^{45}$ zginął, a miałem to zrobić w świcie Jego Cesarzewiczowskiej Mości Księcia Napoleona Bonaparte, jako rysownik tej scjentyficznej ekspedycji - ale zmniejszono świtę i Książę raczył żałować, iż mnie odmówić musiał - w czym wszelako wiele przyczynił się pan Edmund kawaler trzech orderów, adiutant księcia. (przyjaciel.)

Nie bardzo mi tak o to szło jako o honor, ale jako o użyteczność rzeczy, i wyraziłem to, starając się, że broń Boże nie chodzi mi o miejsce honorowe.

[...] końcem końców w 33 roku takiego życia skołatany jestem [...] (List do M. Trębickiej, DW XI, 80) ${ }^{46}$.

Wydarzenie to, stawiające pod znakiem zapytania wartość przyjaźni żywionej przez „pana Edmunda” dla Norwida, z pewnością walnie przyczyniło się do ochłodzenia wzajemnych relacji. Chociaż trwały one jeszcze do lat co najmniej siedemdziesiątych, to jednak nigdy nie osiągnęły już intensywności ani serdeczności z czasów warszawskich.

Norwid nie zobaczył zatem mórz północnych ani ojczyzny Edd. Można tylko niezmiernie żałować, że i ta szansa na wzbogacenie jego twórczej wyobraźni oraz wiedzy została mu odebrana, zapewne z wielką stratą dla polskiej literatury i kultury. Podróż ta mogła odmienić dramatyczny los poety, któremu, jak stale ubolewał, nie pozwolono nigdy „być użytecznym”. Jak zwykle zabrakło niewiele: „Nieraz, zaprawdę, cztery kroki i parę rękawiczek wystarczytoby mi, aby to wszystko odmienić!..." (List do M. Trębickiej, DW XI, 80).

Chojecki, który odwiedził Islandię jako pierwszy Polak w historii ${ }^{47}$, wydał po powrocie obszerną, ponadosiemsetstronicową relację zatytułowaną Voyage dans

\footnotetext{
${ }^{45}$ Admirał sir John Franklin i jego załoga zostali uznani za zaginionych w roku 1845 r. w Przejściu Północno-Zachodnim. Historia fikcyjnej wyprawy mającej na celu odnalezienie uczestników tej pierwszej ekspedycji stała się później (1858) kanwą sensacyjnego pięcioaktowego dramatu Chojeckiego Les mers polaires. Utwór ten był jednym z literackich płodów jego północnej wyprawy.

${ }^{46} \mathrm{Z}$ listu tego J.W. Gomulicki wywnioskował, że Chojecki zajął po prostu miejsce obiecane wcześniej Norwidowi: „W maju albo w czerwcu otrzymuje [Norwid - R.G.-S.] od księcia Napoleona Bonapartego obietnicę wyjazdu w jego świcie, jako rysownik i kronikarz, na pokładzie okrętu 'Espérance', udającego się wkrótce w podróż na morza polarne. W ostatniej chwili obietnica ta zostaje cofnięta, podobno wskutek intryg Edmunda Chojeckiego, 'przyjaciela', który sam zajmuje miejsce przeznaczone dla Norwida (PWsz VIII 263, 268 i 530)”, Kalendarz biograficzny, PWsz XI, 80.

${ }^{47}$ Za pierwszego uważa się niekiedy Daniela Strejcę-Vettera, który był w Islandii w 1613 r., jednak Vetter był spolonizowanym Czechem, który uciekł do Polski przed prześladowaniami religijnymi. Zob. D. VETTER, Islandia albo krótkie opisanie wyspy Islandyji, oprac. D. Rott, Katowice 1997.
} 
les mers du Nord à bord de la corvette La Reine Hortense $e^{48}$, zaopatrzoną w mapę podróży, mapę geologiczną Islandii i dwanaście stalorytów. W Palais-Royal odbyła się również wystawa prezentująca szczegóły wyprawy oraz przywiezione trofea $^{49}$. Publikacja przyniosła autorowi ogromny rozgłos we Francji i cieszyła się ogromną poczytnością (do $1862 \mathrm{r}$. ukazały się aż trzy jej wydania, a książka została entuzjastycznie przyjęta, m.in. przez G. Sand ${ }^{50}$ ). Odegrała też ważną rolę popularyzatorską. Miała nawet poruszyć wyobraźnię Juliusza Verne'a, który od jakiegoś już czasu interesował się podbiegunową, tragicznie zakończoną ekspedycją Franklina, kilka zaś lat po wyprawie Chojeckiego (w roku 1864) wydał powieść o wyprawie do bieguna północnego Voyages et aventures du capitaine Hatteras $^{51}$.

Relacja skandynawska Charles'a Edmonda stała się przedmiotem dwóch szkiców w języku polskim ${ }^{52}$ (szczegóły wyprawy omawia też szeroko w swej książce Desurvire ${ }^{53}$ ), nie ma zatem potrzeby prezentować jej tutaj drobiazgowo. Podobnie jak reportaże krymskie odznacza się ona samodzielnością sądów, krytycyzmem, upodobaniem do zderzania obserwacji z przekazem historycznym, mitycznym i literackim. Chojecki weryfikował baśniowe wyobrażenia zaczerpnięte z $E d d y$, korygował stereotypy (np. sądy o okrucieństwie i barbarzyństwie mieszkańców Islandii i Skandynawii ${ }^{54}$ ), redefiniował pojęcia. Ze względu na polityczną rangę i cesarski prestiż wyprawy jego sprawozdanie nie mogło już mieć charakteru czysto prywatnego, swobodnego lub żartobliwego. Obowiązywała go dyscyplina naukowa, stąd dążenie do narracji bezosobowej i zobiektywizowanego opisu. Mimo tego metodycznego przesunięcia, zgłębiający budowę geologiczną krain podbiegunowych autor okazał się nieodrodnym geognostą romantycznym dystansującym się do „demona nauki”, ", a także romantycznym

\footnotetext{
${ }^{48}$ Ch. EDmond, Voyage dans les mers du Nord à bord de la corvette La Reine Hortense, Paris 1857.

${ }^{49}$ Zob. E. Desurvire, Charles Edmond Chojecki. Patriote polonais, t. I, s. 410.

${ }^{50}$ Zob. K. WeSTERMARK, Między wyobrażonym a realnym końcem świata, s. 72-73.

${ }^{51}$ Zalążkiem tej powieści była napisana w 1855 r. nowela Un hivernage dans les glaces związana z tematyką lodów Północy.

${ }^{52}$ B. PIOTROWSKI, Edmunda Chojeckiego wyprawa na Islandię w $1856 r$.; K. WeSTERMARK, Między wyobrażonym a realnym końcem świata, zob. też Podróże i podróżopisarstwo w polskiej literaturze i kulturze XIX wieku. Studia i szkice, red. A. Kowalczyk, A. Kwiatek, Kraków 2015; W. i T. SŁABCZYŃSCY, Stownik podróżników polskich, Warszawa 1992; T. SŁABCZYŃSKI, Stownik polskich podróżników i odkrywców, Warszawa 2017.

${ }^{53}$ Zob. E. Desurvire, Charles Edmond Chojecki. Patriote polonais, t. I, s. 347-413.

${ }^{54}$ Zob. K. WeSTERMARK, Między wyobrażonym a realnym końcem świata, s. 69.

${ }^{55}$ Ch. EDMOND, Voyage dans les mers du Nord, s. 145.
} 
poetą wrażliwym na piękno natury ${ }^{56}$. W jego dziele uwidacznia się właściwe romantykom spojrzenie na świat $\mathrm{i}$ kulturę, m.in. przekonanie o doniosłej roli mitu. Voyage dans les mers $d u$ Nord odkrywa bowiem przed europejskim czytelnikiem świat nordyckiej mitologii,

[...] panteon północnych bóstw na czele z Odynem i Thorem. Narrator wyraża przekonanie, że dzięki swojej geograficznej izolacji Islandia zachowała wiele z pierwotnych podań i legend, które nadal stanowią podstawę życia intelektualnego jej mieszkańców i są często przekazywane w tradycyjnej ustnej formie. Na dowód przywołuje przykład jednego z obywateli Rejkiawiku, który swoją genealogię wywodził właśnie od Odyna i potrafił wyliczyć przedstawicieli wszystkich łączących go z nim pokoleń. Chojecki opisuje też zetknięcie z językiem staroislandzkim oraz poświęca uwagę kulturotwórczej działalności skaldów. Porównuje ich do celtyckich bardów i homeryckich rapsodów, twórców poezji pierwotnej i nieskażonej przez oddziaływanie zewnętrzne. Eddy poetyckie, historie zebrane przez Saemunda i Snorriego Sturlusona, zalicza do największych skarbów literatury światowej ${ }^{57}$.

Czy publikacja Chojeckiego wywarła jednak jakikolwiek wpływ na Norwida? Można przypuszczać, że przeczytał on sprawozdanie z podróży, o której marzył i z którą wiązał swe artystyczno-scjentyficzne plany. Zapewne nie jest dziełem przypadku, że tematyka skandynawska (nordycka) pojawiła się w jego poezji właśnie w roku 1857 . Wtedy to powstał stanowiący ogniowo poetyckiego dialogu wiersz Odpowiedź [Jadwidze Łuszczewskiej], pełen reminiscencji z mitologii Północy:

Lecz na północy... nie etruska mowa;

Marmur się kończy, gdzie lody -

I młot Odyna, nie długo, w nich kowa

$\mathrm{Ku}$ innym światom przechody!*

*Wedle tak podań północnych, jako też wiary, a nawet mniemań klasycznych starożytnych historyków, pasmo pod biegunem północnym mrokami swymi daje przejście dla duchów na planetę (PWsz I, 322-323).

Inspiracje te mógł Norwid zaczerpnąć właśnie z książki Chojeckiego, choć równie dobrze mogła ona stać się po prostu impulsem do głębszego zainteresowania się kulturą Północy. Poeta prawdopodobnie czynił też intelektualne przygotowania do wyprawy już na etapie jej planowania, zgłębiając literaturę przed-

\footnotetext{
${ }^{56}$ Zob. K. WESTERMARK, Między wyobrażonym a realnym końcem świata, s. 68, 71-72.

${ }^{57}$ Tamże, s. 70.
} 
miotu. Tak czy inaczej, echo ekspedycji Edmunda do lodów Skandynawii wyraźnie pobrzmiewa w Norwidowskiej twórczości ${ }^{58}$.

\section{CZĘŚĆ III. CHOJECKI, NORWID I EGIPT. WYSTAWA ŚWIATOWA W PARYŻU W 1867 ROKU}

Chojecki miał jeszcze raz odegrać ważną, inspirującą rolę w życiu Norwida-twórcy. To właśnie jemu przypadł główny, jak się wydaje, udział w narodzinach Norwidowskiego zamysłu stworzenia dzieła literackiego o tematyce egipskiej. Oczywiście pierwszy impuls pochodził, jeszcze w czasach warszawskich, od polskiego romantycznego odkrywcy „starożytnego świata” - Władysława Węży$\mathrm{ka}$, jednak to ostatecznie właśnie Edmund miał zarazić Cypriana pasją egiptologiczną, a nawet stać się jego przewodnikiem po kraju faraonów na paryskiej Wystawie Powszechnej w roku 1867.

Chojecki gruntownie poznał Egipt już w latach pięćdziesiątych, spędził tam bowiem ponad rok wygnania ${ }^{59}$, od czerwca 1850 do lipca $1851^{60}$ (w trakcie tego pobytu poznał Gustava Flauberta). Nie była to zsyłka aż tak uciążliwa, jak mogłyby to sugerować korespondencyjne skargi autora. List polecający od

\footnotetext{
${ }^{58}$ I pobrzmiewać będzie do lat ostatnich; w artykule „Żydy” $i$ mechesy z roku 1882 Norwid, nie po raz pierwszy zresztą, przypisze sobie północną (normańską) genealogię, przywołując przy tej okazji bóstwa nordyckie: „Dziadowie moi wyznawali naprzód Odyna-poświęcenie, potem Krywekrywejty, aż za dni Jagiełly przechrzcili się” (PWsz VI, 649).

Rozmaite artefakty z krajów skandynawskich poeta mógł oglądać na Wystawie Światowej w Paryżu w roku 1867:

„Kraje skandynawskie dostarczyły najciekawszych zabytków, odnoszących się do pierwotnej, przedhistorycznej epoki. [...] Muzeum starożytności w Kopenhadze nadesłało część swoich zbiorów, mianowicie narzędzia z krzemienia i granitu, które po większej części mają kształt młota bóża Thora $\mathrm{z}$ legend skandynawskich. Zwykle za rękojeść tym młotom służy róg Rena albo kość wołu”, Listy w wystawy paryskiej, „Dziennik Poznański” 1867, nr 177, s. 3.

O zainteresowaniu Norwida mitologią i kulturą Północy pisali: E. Kasperski w swej książce Dyskursy romantyków. Norwid i inni, Warszawa 2003 oraz E. Lijewska, $O$ dwóch Quidamach. Norwid - Kierkegaard, [w:] ,,Quidam”. Studia o poemacie, red. P. Chlebowski, Lublin 2011, s. 452-455.

${ }^{59}$ Jego powodem było zaangażowanie pisarza w działalność polityczną radykalnych kół, przede wszystkim współpraca z Proudhonowskim pismem „La Voix du peuple”.

${ }^{60}$ Zob. E. Desurvire, Charles Edmond Chojecki. Patriote polonais, t. I, s. 91.
} 
ks. Napoleona ${ }^{61}$ otworzył Chojeckiemu drzwi kairskiego pałacu generała Solimana Paszy, zmuzułmanionego Francuza (właściwe nazwisko: Joseph Sève ${ }^{62}$ ), pozostającego niegdyś w służbie u Mehmeda Ali, a wówczas głównodowodzącego armii egipskiej. Ten uczynił Polaka swym gościem i sekretarzem w sztabie ${ }^{63}$.

W kraju faraonów Edmund oddawał się badaniom antropologicznym (zafascynowany był głośnym już w ówczesnej nauce ewolucjonizmem) i archeologicznym, uczył się także języka arabskiego. Odwiedzał wspaniałe zabytki z czasów faraonów, przemierzył cały Górny Egipt. Ten zapalony socjalista i współpracownik Proudhona miał również okazję zderzyć teorie socjalistyczne z niesprawiedliwością społeczną i nędzą ówczesnego Egiptu ${ }^{64}$.

Kilka miesięcy po przybyciu do Kairu Chojecki otrzymał list od Norwida (niezachowany i dziś niestety nieznany), który to dowód pamięci przyjaciela wyraźnie go rozrzewnił. Wyrwał go bowiem z osamotnienia i wygnańczej izolacji, rozproszył ogarniające go zewsząd poczucie bezużyteczności. Wdzięczny i wzruszony odpowiadał 25 października 1850 r.:

Kochany Cyprianie!

Dziękuję Ci za Twój list; drogi on byłby w Egipcie dla każdego mieszkańca Europy; dla mnie jest nieoceniony, dla mnie, który żyję tylko jałmużną przyjacielskich słów, kiedyniekiedy z dala mi rzucanych. Przeniesienie się z burzliwego życia w Paryżu śród samotności afrykańskich pustyń było dla mnie, Bóg widzi, ciężką przeprawą. Pozbawiając go naturalnego mu pokarmu, zadałem gwałt memu charakterowi; poraniłem się i srodze rozbolałem.

W odosobnieniu smutki dojrzewają i gorycze ścinają się w dotykalne niemal kształty. W Paryżu od dawna już miałem nogę w strzemieniu, pędziłem na utorowanej własnym

\footnotetext{
${ }^{61}$ Księcia Napoleona znał też osobiście książę Marceli Lubomirski, z którym Norwid się zaprzyjaźnił się w Ameryce (i który w ogóle umożliwił poecie powrót do Europy, opłacając mu bilet powrotny).

${ }^{62}$ Zob. E. DesUrvire, Charles Edmond Chojecki, l'Oeuvre et la Vie, s. 74.

${ }^{63}$ Chojecki proponował Solimanowi Paszy spisanie jego pamiętników. Planował też wysyłać do Francji dwa razy w tygodniu korespondencję prasową (felietony z Egiptu). Zob. E. Desurvire, Charles Edmond Chojecki. Patriote polonais, t. I, s. 102.

Mimo że Chojecki znalazł się w luksusowych warunkach (mieszkał w pałacu nad brzegiem Nilu, mógł korzystać ze wspaniałej pałacowej biblioteki, brać udział w ucztach i polowaniach), egipskie wygnanie nie budziło jego entuzjazmu: „[...] dla mnie życie to działanie, i z tego punktu widzenia na Wschodzie nie ma niczego, co przypomina życie". List E. Chojeckiego do ks. Napoleona z 10 X 1850 roku, [w:] Ch. EDMOND. Correspondance, s. 22 (list nr 36). O ile nie zaznaczono inaczej, tłumaczenia francuskich tekstów Chojeckiego pochodzą od autorki niniejszej publikacji.

${ }^{64}$ Sporo uwag na temat ówczesnego Egiptu zawarł Chojecki w listach do Proudhona. Ten ostatni pozostawał jego najważniejszym korespondentem w tamtym czasie.
} 
trudem drodze; cel widziałem przed sobą; byłbym go dopiął; przyszłość moją miałem w dłoni i modelowałem ją dowolnie, jak wosk w rozgrzanej stalowej rękawicy. Wszystko musiałem porzucić; troski tylko z sobą wywiozłem; a co jeszcze na przyszłość wypadnie mi porzucić, o tym wie tylko los-kuglarz, który igra sobie z moim życiem jak z mosiężną kulą, nie bacząc, gdzie mu takowa z rąk złośliwych wypadnie. Dziś kuję sobie pancerz, którego podobno nigdy ukuć nie potrafię, obojętność. [...]

To, co mówią w Paryżu o przyjęciu, jakiego doznałem w Egipcie, gęsto wyhaftowane jest fałszem. Seraskier Basza przyjął mnie jak człowieka, który mu przywiózł czternaście listów od znakomitych we Francji osób. Zdało mu się, że i w Egipcie mogę na coś się przydać; toczył ze mną długie rozmowy; przyszłość pokaże, jaki był skutek tych rozmów, gdzie z jednej strony pewna, na wpół dzika szlachetność, w krwi umyta energia i serdeczna przyjaźń ku Polakom szła w zapasy z panującym nade wszystko uczuciem niepodległości i rozfatalizowaną przeciw samemu sobie niechęcią ${ }^{65}$.

W dalszej części listu znalazły się szczegóły dotyczące sytuacji wewnętrznej Egiptu:

Cywilizacja europejska zależy na drwieniu w Koranu i upijaniu się winem. Tymczasem podziemnymi nurtami tętnią intrygi, ludzie znikają; zaraza, cholera, oftalmie dziesiątkują naród. Reszta głaszcze skrycie jatagany. Śród tego pandemonium żyje Seraskier-Basza, surowy w obyczajach jak pustelnik dawnej Tebaidy, zastygły w żołnierskiej srogości, nienawidzący teraźniejszości i kochający władzę. Fatalizm i pogarda życia - oto dwa uczucia, które tu mimowolnie chwytają za duszę, i absolutnie owładają umysłem. Tysięczne siły pędzą cię na tę drogę.

W nocy siądź w moim oknie, z którego rękę możesz w Nilu umoczyć; obaczysz naprzeciw wysepkę [...]. Jest to miejsce przeznaczone na topienie worków. W workach tych zaszyta jest zwykle kobieta z kotem. [...] Wyjrzysz bramą: na lewo biegnie droga z Abisynii; tam często Murzyny się buntują lub nie chcą płacić podatków. Na drodze tej łatwo spotkasz Arnautów, każdy z kilka czarnymi głowami uwiązanymi u siodła. To dzieje się tam, gdzie mieszkają Turcy, a o czym chrześcijańskie części miasta nic nigdy nie wiedzą. [...]

Lud tutejszy jest podupadły na duchu i zdemoralizowany niewolą. Beduiny tylko są istotnie bohaterskim plemieniem. Żują oni wędzidło i w pień klną ciemiężców ${ }^{66}$.

Na koniec Chojecki odkrywał przed przyjacielem swe ambitne plany naukowo-podróżnicze:

Co do mnie, na drugi dzień przyjazdu zacząłem zaraz uczyć się po arabsku. Dziś krążę już po meczetach i namiotach i mogę dostatecznie się rozmówić; za rok spodziewam się znać język zupełnie. [...]

\footnotetext{
${ }^{65}$ E. ChoJeCKI, List do C. Norwida z 25 X 1850 roku, [w:] Ch. EDMOnd, Correspondance, s. 24 (list nr 38).

${ }^{66}$ Tamże.
} 
Zimę przepędzę w Kairze, gdzie chciałbym z arabską mową i z Koranem się ułatwić. Na przyszły rok, jeżeli dożyję, a nadzieje mnie nie zawiodą, zapuszczę się głębiej w Saharę. Zbiegnę pokolenia Beduinów między Gazą i Al.-Harisz, zaczepię Jeruzalem, Bagdad, Aleppo, zwłaszcza zaś Liban. Syria daleko jest ciekawszą od Egiptu. W Sennaar [Maksymilian] Ryłło dziwne zostawił pamiątki. Historia tego człowieka, walczącego za pomyślność jezuitów na Wschodzie, jest nader zajmującą.

Czy wrócę do Francji i kiedy?... byłbym oddał życie, aby w niej pozostać; dziś wolałbym je stracić, aniżeli do niej powrócić. Czasami napadają mnie chwile żalu i rozpaczy... Wiesz z doświadczenia, co kosztują człowieka nerwy! Chciałbym być Ci tu w czym użytecznym; powiedz, mój drogi, jak mogę to uczynić i nie zapominaj o szczerym przyjacielu i bracie.

C. E. ${ }^{67}$

List ten Norwid przesłał Władysławowi Bentkowskiemu do redakcji poznańskiego „Gońca Polskiego” „dla malowniczości ustępów” (List Norwida do W. Bentkowskiego z 3 grudnia 1850 r., DW X, 294-295). Został on opublikowany (w całości) na łamach pisma 27 listopada 1850 r. (w numerze 126 na stronach 491-492), nawet bez powiadomienia o tym fakcie Norwida, który jeszcze w grudniu zastrzegał, by Bentkowski upublicznił jedynie fragmenty niemogące nikomu zaszkodzić (,są tam imiona osób, i pasportowych nawet, jeżeli się nie mylę", DW XI, 294).

Później emigracyjne życie paryskie dostarczało przyjaciołom różnych okazji do spotkań: to na święconym w Szkole Polskiej na Batignolles w roku $1860^{68}$, to na wieczorach poetyckich u Deotymy ${ }^{69}$. W 1861 Norwid opowiadał o Chojeckim Józefowi Bohdanowi Zaleskiemu ${ }^{70}$. Wspólnie umieszczali też swoje utwory w pamiątkowych zbiorkach „upominkowych” (Po ziarnie 1861) ${ }^{71}$. W roku 1861 Edmund otrzymał obywatelstwo francuskie, co radykalnie odmieniło jego sytuację społeczną i finansową (umożliwiało porzucenie kondycji emigranckiej i piastowanie urzędów francuskich).

Egipskie doświadczenia i znajomości z lat pięćdziesiątych przydały się Chojeckiemu kilkanaście lat później, gdy zrodziła się myśl zorganizowania ekspozycji egipskiej na Wystawie Powszechnej w Paryżu w roku $1867^{72}$.

${ }^{67}$ Tamże.

${ }^{68}$ Zob. Z. TrojanOwiCZOWA, Z. DAMBEK, Kalendarz, s. 778.

${ }^{69}$ Zob. tamże, s. 798.

${ }^{70}$ Zob. tamże, s. 26.

${ }^{71}$ Zob. tamże, s. 52.

${ }^{72}$ Chojecki udał się do Egiptu już w styczniu 1866 r. w celu podjęcia rozmów na temat udziału Egiptu w wystawie. Pozostał tam dwa i pół miesiąca. O jego udziale w organizacji działu egipskiego zob. E. DESURVIRE, Charles Edmond Chojecki. Patriote polonais, t. II, s. 163-169. 
Ogromne zainteresowanie Francuzów (i Europejczyków w ogóle) Egiptem wywołała już na początku XIX stulecia wyprawa Napoleona $(1798-1801)^{73}$ oraz będąca jej owocem dwunastotomowa praca Description de l'Égypte (1809-1822) - wszechstronny naukowy opis kraju faraonów ${ }^{74}$. W ten oto sposób Napoleon zwrócił uwagę świata na Egipt, niezwykły geniusz Orientu i zarazem potrzebę reform w tej części świata.

Wystawę powszechną, czynną od 1 kwietnia do 3 listopada 1867 r., zorganizowano na wojskowych Polach Marsowych (i na île de Billancourt). Pewną jej cześć pomieścił zbudowany specjalnie na tę okazję olbrzymi Palais Omnibus ${ }^{75}$. Już sama jej idea budziła entuzjazm:

W kilku promenadach (podczas kilku spacerów) będzie możliwe odbyć podróż dookoła świata, poprzez wszystkie epoki, przez cały czas zapełniony przez człowieka i przeżyty przez niego. Co za marzenie! ${ }^{76}$

Mecenasem ekspozycji egipskiej był ówczesny wicekról Egiptu Ismael Pasza, rządzący krajem dopiero od czterech lat, światty, zapalony reformator wykształcony w Paryżu (dwa lata później, w roku 1869, miał on patronować także uroczystości otwarcia Kanału Sueskiego). Osobiście uczestniczył w przygotowaniach, zarówno części artystycznej, jak i industrialnej, powołał też specjalną komisję pod prezydencją Nubara-Paszy (jego prawej ręki w Egipcie), która miała zając się realizacją projektu. Komisarzem generalnym ekspozycji, odpowiedzialnym za bezpieczeństwa obiektów oraz realizację rozkazów władcy w Paryżu, został Polak - Edmund Chojecki, pozostałymi członkami komisji byli: najwybitniejszy ówczesny egiptolog i archeolog francuski August Mariette (1821-1881), pułkownik Mircher (pod kierunkiem którego przygotowano plan reliefowy Egiptu); Antonio Figari (1804-1870) - włoski farmaceuta i naturalista, autor dzieła Studii scientifici sull'Egitto e sue adiacenze, compresa la penisola dell'Arabia Petrea (Lucca 1864), któremu ekspozycja zawdzięczała swą część sudańską oraz mapę geologiczną (owoc dwudziestu pięciu lat pracy jego i jego kolegów-

\footnotetext{
${ }^{73}$ Napoleon zabrał z sobą do Egiptu 167 naukowców, którzy mieli zbadać kraj faraonów (będący wtedy pod władaniem imperium osmańskiego) i jego historię.

${ }^{74}$ Prócz zastępu naukowców przy Description pracowało około 2000 rysowników.

${ }^{75}$ Budynek miał 325 metrów długości i 110 metrów szerokości, do środka prowadziło aż szesnaścioro drzwi. Pałac rozebrano po zamknięciu ekspozycji, gdyż nie mógł on dłużej zajmować potrzebnych terenów wojskowych. Zob. https://paryz.pl/wystawa-swiatowa-w-paryzuw-1867-roku/ (dostęp: 23.11.2018).

${ }^{76}$ Ch. Edmond, L'Égypte a l'exposition universelle de 1867, Paris 1867, s. 14-15.

Zob. też Exposition universelle de 1867 à Paris. Documents iconographiques, Paris 2008.
} 
mineralogów ${ }^{77}$ ); J. Claude - członek międzynarodowego Komitetu pieniędzy, wag i miar, oraz Vidal, który przygotowywał katalog wystawy. Za prace architektoniczne odpowiadał Drevet, za malarskie - malarz historyczny Bin, a za rzeźbiarskie - dwaj inni artyści: Mallet i Godin ${ }^{78}$.

Największym autorytetem w tym zacnym gronie pozostawał Mariette - założyciel Egipskiego Departamentu Starożytności, uczony, którego odkrycia zapewniły dziewiętnastowiecznej egiptologii solidny fundament (Chojecki uważał go za człowieka bardziej zasłużonego niż Champollion, ten ostatni bowiem jedynie „nauczył świat czytać książkę, którą zajmuje się Mariette, by odtworzyć ją dla świata" ${ }^{, 79}$ ). Mariette dokonał w Egipcie wielu fascynujących odkryć: odkopał Serapeum - hypogeum świętych byków Apisów w Sakkarze (1850), zbadał nekropolie w Meidum, Abydos i Tebach, wielką świątynię w Denderze, wydobył spod piasków świątynię Horusa w Edfu, prowadził prace w Karnaku (zob. jego Karnak, étude topographique et archéologique, Paris 1858), Medinet Habu, Deir el-Bahari, Tanis, odsłonił Świątynię Sfinksa w Gizie. To on rozpoczął metodyczne, naukowe badanie świątyń egipskich i utworzył w 1857 roku pierwsze muzeum gromadzące zabytki Egiptu w Bulak (północnej dzielnicy Kairu) ${ }^{80}$. Stało się ono zalążkiem Muzeum Egipskiego w Kairze.

Decyzją Ismaela Paszy na Wystawie Światowej w Paryżu została pokazana właśnie spora część zbiorów z Bulak, pochodzących z wykopalisk Mariette’a (m.in. papirusy, rzeźby, biżuteria), a zatem wybór rzeczy niezwykle rzadkich, autentycznych i cennych, reprezentatywnych dla Egiptu faraonów. To przeniesione wprost z Kairu do Paryża muzeum stanowiło nie lada gratkę dla tych, którzy nie mogli sobie pozwolić na wyprawę do kraju nad Nilem (jak Norwid).

Ekspozycja egipska, prezentująca dorobek kilku tysięcy lat cywilizacji powstałej nad Nilem, zainstalowana w północno-zachodnim rogu Pól Marsowych, na ogromnej powierzchni 6 tysięcy metrów kwadratowych, prezentowała olśnio-

\footnotetext{
${ }^{77}$ Figari, który przybył do Egiptu mając 21 lat, pracował najpierw w kairskim szpitalu, później prowadził przez kilkanaście lat misję geologiczną na pustyni egipskiej. Jej celem było znalezienie złóż węgla i marmuru.

${ }^{78}$ Zob. Ch. EDMOND, L'Égypte a l'exposition universelle, s. 15.

${ }^{79}$ Tamże, s. 43. Ciekawostką jest to, że Giuseppe Verdi napisał libretto do opery Aida według tekstu napisanego przez Mariette'a.

${ }^{80}$ By położyć kres archeologicznej samowoli i swobodnemu wywożeniu zabytków Egiptu, Said Pasza powołał w 1858 r., ku zadowoleniu całego środowiska archeologicznego, Service générale de conservation des antiquites de l'Égypte, zajmujący się ochroną i rekonstrukcją zabytków. Wtedy też zrodziła się potrzeba wybudowania odpowiedniego gmachu dla muzeum w Kairze. Powstał on dopiero w roku 1902, wcześniej przechowywano eksponaty w pałacu Ismaila Paszy w Gizie (jeszcze wcześniej w Bulak, w cytadeli Saladyna i w magazynach kairskiej szkoły językowej).
} 
nym zwiedzającym Egipt w miniaturze: „,wspaniały, odsłaniający wielkość swojej przeszłości, bogate obietnice teraźniejszości, pozostawiając opinii publicznej staranie o wyciągnięcie z tego wniosków na temat przyszłości”81. Kącik egipski został jednogłośnie obwołany najciekawszym pośród wszystkich cudów i niezwykłości Wystawy Światowej ${ }^{82}$. Paryski korespondent „Dziennika Poznańskiego" pisał o nim z entuzjazmem:

Kto poszukuje istotnego kolorytu i niekłamanej malowniczości, ten znajdzie to oboje w części parku zajętej przez egipską wystawę. Jest to jeden z najciekawszych i najbardziej pouczających działów ekspozycji. Znajdują się tu cztery zabudowania odmiennej architektury i całkiem odmiennego przeznaczenia: karawanseraj, świątynia, pałac i stajnie.

Karawanseraj, czyli okel, jak mówią na Wschodzie, jest rodzajem krużganku, otaczającego obszerne, prostokątne podwórze. Poumieszczano tam kramy i sklepy rozmaite; siedzą przed nimi rzemieślnicy egipscy i bardzo gorliwie pracują. Są między nimi typy przepyszne, prawdziwie biblijne, jakby z obrazów wyjęte. Jubilerowie z Kairu i Sudanu szlifują i oprawiają klejnoty, tokarze wiercą długie do fajek cybuchy, inni znów splatają rogoże [maty z sitowia - R.G.-S.] lub szmuklerskie [pasmanteryjne - R.G.-S.] z jedwabiu wyrabiają ozdoby: jest nawet balwierz czekający, czym mu kto brody swej do golenia nie powierzy.

W głębi znajduje się kawiarnia, gdzie można palić nargilę, popijając mokę na sposób wschodni przyprawioną. Słowem, cały ten karawanseraj daje tym, co na Wschodzie podróżowali, istotne przypomnienie tamtych krajów [...]. Dół karawanseraju zajęty jest przed Egipt teraźniejszy, żywy i ruszający się, na górnym piętrze spoczywa Egipt starożytny i martwy, przedstawiony przez 12 mumii.

W pałacu oglądać można wielki, wypukły plan całego Egiptu, bardzo ciekawie i umiejętnie wykonany przez inżynierów francuskich: zebrano tam także piękne odbicia fotograficzne wszystkich najznakomitszych ruin i pomników. W stajniach znajdują się dwa dromadery, należące do dwóch ras odmiennych. [...] Dają się tam także widzieć dwa osły, czarny i biały: oba w kwiecie wieku, zgrabne, wysmukłe, z sierścią lśniącą się i gładką, są one istotnie ideałem osłów.

Przed świątynią egipską, która pod względem historycznym i artystycznym istotną przedstawia wartość, poważne zaległy sfinksy. [...]

Epoka współczesna piramidom przedstawiona jest $\mathrm{w}$ sali środkowej. Sztuka $\mathrm{z}$ epoki współczesnej Mojżeszowi rozłożyła się tu na murach zewnętrznych, a okres Ptolemeuszów pod kolumnadą, otaczającą cały budynek. Wszystkie malowidła, jakie tu widzieć się dają, kopiowane z pomników i grobowców egipskich, są dziełem biegłego artysty, p. Bin. Posągi $\mathrm{z}$ alabastru, marmuru i drzewa, nadesłane $\mathrm{z}$ muzeum w Bulak, zaludniają całą świątynię. Jest tu bardzo piękna statua królowej Ameniritis z 25 dynastii! ${ }^{83}[\ldots]$

${ }^{81}$ Ch. Edmond, L'Égypte a l'exposition universelle, s. 15. Wznoszeniu konstrukcji ekspozycji nie sprzyjała pogoda (jak podaje Chojecki, na 90 dni przypadło aż 68 deszczowych, później nastały zimowe chłody i mrozy).

${ }^{82}$ Tamże, s. 18.

${ }^{83}$ Mowa o alabastrowym posągu córki kuszyckiego władcy - faraona Kaszty (VIII wiek przed Chr.), znalezionym w Tebach. 
Widziałem tu między innymi bardzo piękne klejnoty kobiece, pierścienie, kolczyki i naszyjniki, należące do królewny Aach-hotep. [...] dowiaduję się, że królewna Aachhotep, której mumię niedawno z klejnotów odarto, żyła za panowania króla Tanis, to jest właśnie wtedy, kiedy Józef syn Jakuba został prezesem egipskiego ministerium.

Urządzeniem całej egipskiej wystawy zajmuje się tutaj p. Edmund Chojecki ${ }^{84}$.

Przekażmy jednak głos samemu komisarzowi wystawy:

Wejdźmy. To jest muzeum. Przed naszymi oczami cały Egipt starożytny, na wyciągnięcie ręki, we wspaniałym résumé [...]. Tłoczone reliefy, malowidła najprecyzyjniej skopiowane z oryginałów, stelle wypełnione inskrypcjami dużo starszymi od samej Biblii, które nauka umie odczytać; biżuteria z wykopalisk wykonana z masywnego złota, z czasów, gdy powstawały piramidy; statuy nieporównywalnie doskonałe i pełne życia, które spały, 30, 40 bądź 50 wieków, w grobowcach; mumie odpoczywające w swoich trumnach, zdające się niemal opowiadać o całej wieczności. Nawet dla profana wrażenie jest niezwykle uroczyste. Wszystko zostało wybrane i ułożone w naukowym, przemyślanym porządku tak, [...] by odtworzyć w myślach najstarszą cywilizację ludzką, z jej religią, polityką, sztukami, przemysłem, obyczajami, zwyczajami, wielkimi imionami i wielkimi wydarzeniami z jej dziejów ${ }^{85}$.

Części starożytnej egipskiej wystawy patronował budynek świątyni o wymiarach 18 na 48 metrów (w Karnaku było to 370 metrów, obiekt paryski stanowił zatem świątynię w miniaturze, raczej rodzaj „kaplicy”, jak zauważał Mariette ${ }^{86}$ ), wzorowany na planie, proporcjach i detalach świątyni bogini Izydy z wyspy File $^{87}$.

Przedmioty z epoki kalifów wystawione zostały w oprawie architektonicznej Salemliku (pałacu otomańskiego ${ }^{88}$ ); w ten sposób „kapłańska surowość i królewski splendor epoki faraonów kontrastowały z arystokratyczną lekkością i rycerskim wdziękiem" ${ }^{\prime 9}$. Dorobek Egiptu współczesnego prezentowany był w budynku użyteczności publicznej - Okelu, wzorowanym na karawanserajach z Górne-

${ }^{84}$ J.S., Listy z wystawy paryskiej, „Dziennik Poznański” 1867, nr 124, s. 4.

${ }^{85}$ Ch. EDMOND, L'Égypte a l'exposition universelle, s. 18.

86 „Nous aurions eu ainsi un temple en quelque sorte détaché du sol égyptien, et transporté au Champ-de-Mars", A. MARIETTE, Exposition universelle de 1867. Description du Parc egyptien, Paris 1867, s. 10-11.

${ }^{87}$ Zob. Exposition Universelle de Paris 1867. Temple égyptien, https://www.worldfairs. info/expopavillondetails.php?expo_id=3\&pavillon_id=3744 (dostęp: 20.11.2018). Zob. też Z. ÇELIK, Displaying the Orient: Architecture of Islam at Nineteenth-Century World's Fairs, Berkeley-Los Angeles-Oxford 1992.

${ }^{88}$ Zob. Exposition Universelle de Paris 1867. Salemlik, https://www.worldfairs.info/ expopavillondetails.php?expo_id=3\&pavillon_id=3599 (dostęp: 20.11.2018).

${ }^{89}$ Ch. EDMOND, L'Égypte a l'exposition universelle, s. 190. W Pałacu wyeksponowany był reliefowy plan Egiptu. Zob. A. MARIETTE, Exposition universelle de 1867, s. V. 
go Egiptu, stanowiącym połączenie hotelu, oberży, bazaru, sklepu, atelier i giełdy (był on porównywany przez Chojeckiego do paryskiej galerii) ${ }^{90}$. Autorem ostatnich dwóch projektów był Schmits, architekt Ministerstwa robót publicznych w Kairze. W bezpośredniej bliskości Okelu znajdowała się jeszcze wspominana wyżej stajnia z dwoma osiołkami i dwoma dromaderami.

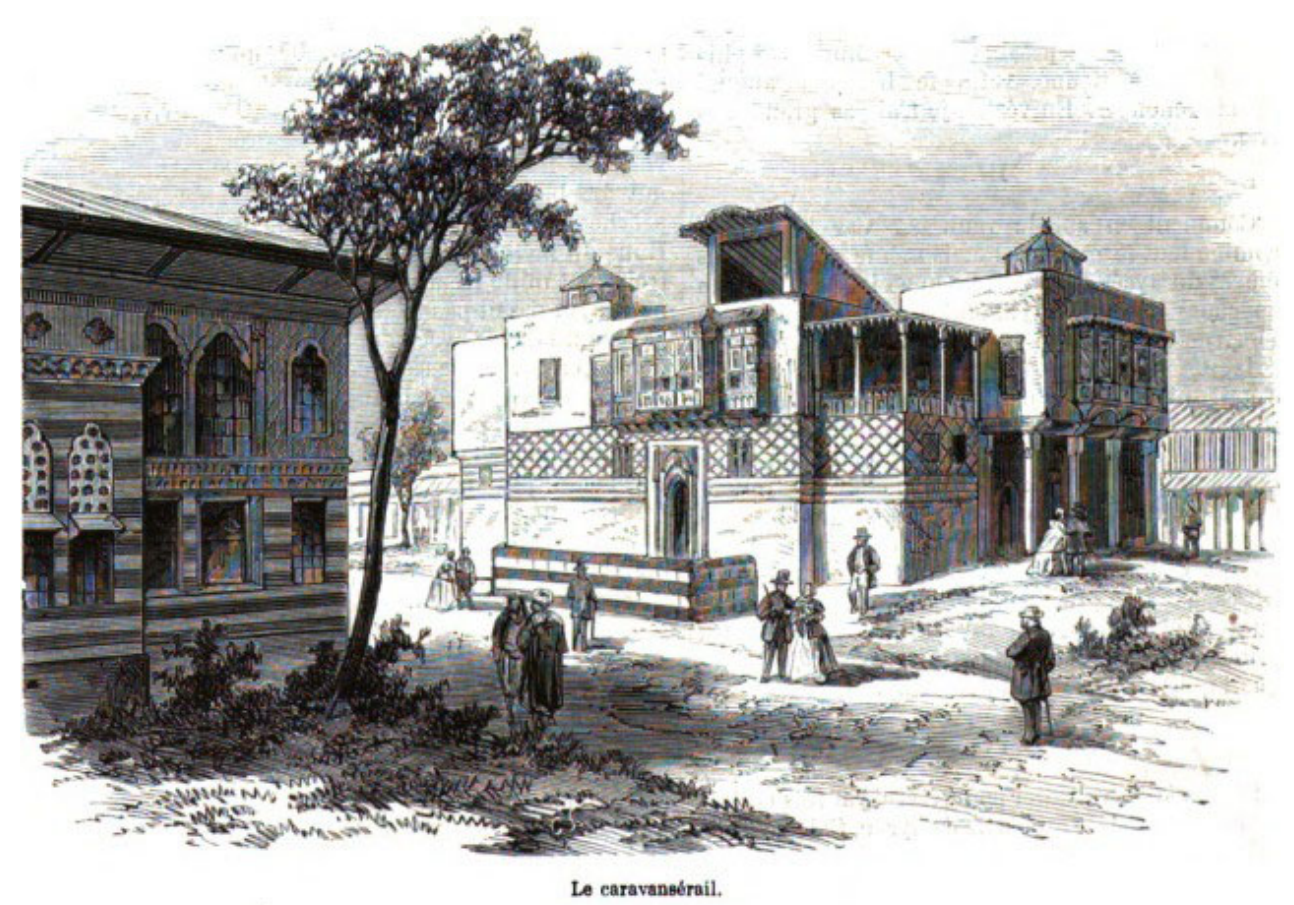

Il. 1. Budynek karawanseraju na Wystawie Światowej (,L'Illustration” z 30 marca 1867, s. 201)

\footnotetext{
${ }^{90}$ Zob. Exposition Universelle de Paris 1867. Okel (Okala), https://www.worldfairs.info/ expopavillondetails.php?expo_id=3\&pavillon_id=3756 (dostęp: 20.11.2018).
} 
Wydana przez Chojeckiego jeszcze w tym samym roku w Paryżu publikacja, zatytułowana L'Égypte à l'Exposition universelle de 1867, nie była zwykłym systematycznym katalogiem wystawy, ale uczonym kompendium, prezentującym bardzo drobiazgowo, a zarazem w sposób przystępny, stan ówczesnej egiptologii (m.in. przyjmowaną wówczas chronologię dziejów Egiptu ${ }^{91}$, nierzadko różniącą się od akceptowanej obecnie; znane zabytki, a także rezultaty najnowszych odkryć archeologicznych). Jej część archeologiczną ubogacił zaprzyjaźniony $\mathrm{z}$ autorem Mariette, swoich prac i rezultatów badań użyczyli też przedstawiciele Comité de monnaies, poids et mesures: Figari i Claude ${ }^{92}$. Studium Chojeckiego pozostaje do dziś fundamentalnym źródłem informacji o egipskiej części ekspozycji paryskiej w 1867 r. ${ }^{93}$, bezcennym dla naukowców, historyków, muzealników i archeologów (obok Expositions universelle de 1867. Description du parc égyptienne: Mariette'a-Beya ${ }^{94}$ ).

Liczące ponad 380 stron dzieło składa się z ułożonych chronologicznie trzech części poświęconych kolejnym fazom dziejów Egiptu (odpowiadały one zarazem trzem sektorom ekspozycji egipskiej w Paryżu): Egiptowi starożytnemu (Egiptowi faraonów), wiekom średnim (arabskiemu Egiptowi kalifów) i wreszcie Egiptowi nowoczesnemu (Ismaela Paszy). Każdy z rozdziałów zawiera szkic historyczny, szczegółowy opis zabytków z danej grupy oraz informacje o ich rozmieszczeniu na wystawie. Na końcu publikacji zostały jeszcze zebrane dane statystyczne (opracowane przez pułkownika Mircher) dotyczące powierzchni kraju, liczby ludności, handlu, wojskowości i floty, finansów itp. oraz katalog prezentowanych na wystawie przedmiotów podzielony na grupy tematyczne (tym razem bez zachowania chronologii).

Chojecki nazywał Egipt „ojcem świata”, „dziełem kaprysu i fantazji natury”, który swój niebywały rozkwit zapewniał splotowi zadziwiającej przychylności natury i ludzkiego geniuszu. Uświadamiał czytelnikom radykalną różnicę między

\footnotetext{
${ }^{91}$ Chojecki trzymał się chronologii dziejów Egiptu przyjętej przez niemieckiego egiptologa Heinricha C. Brugscha w jego Histoire d'Égypte, Leipzig 1859. Zob Ch. EDMOND, L'Égypte a l'exposition universelle, s. 39.

${ }_{92}$ Zob. tamże, s. 11.

${ }^{93}$ Zob. np. A. Nour, Egyptian-French Cultural Encounters at the Paris Exposition Universelle of 1867, „MDCCC 1800” 6(2017).

${ }^{94}$ Obok relacji spisanej przez archeologa A. MARIETTE, Exposition universelle de 1867. Description du Parc egyptien; TENZE „Document”. Communications on the Egyptian Exhibition of 1867 (Murassallat bi khousus maarad al Masri li aam 1867), Cairo 1866: Egyptian National Archives of Egypt (Dar al-Wathaiq al-Qawmiyya), 5013-004219 oraz L'Exposition universelle de 1867 illustrée: publication internationale autorisée par la Commission imperiale, red. F. Ducuing, Paris 1867, t. I-II.
} 
stanem Egiptu dziewiętnastowiecznego, a potencjałem demograficznym i gospodarczym tego kraju w czasach faraonów i kalifów ${ }^{95}$. Zwracał również uwagę na niewyobrażalną dla Europejczyków rozpiętość czasu i przestrzeni, związaną z rozwojem cywilizacji egipskiej (dopiero po dwudziestu wiekach od jej zarania powstały piramidy i Memfis, Memfis zaś oddalone było od Teb, jak Babilon od Paryża $^{96}$ ). Przypominał, że cywilizacja Egiptu starsza jest od Babilonu i Niniwy, w czasach Persów liczyła już pięć tysięcy lat ${ }^{97}$, a rozkwitała, gdy ludy mające w przyszłości zamieszkać Europę, błąkały się jeszcze po stepach Tartarii, wiodąc na wpół zwierzęce życie. Pośród tej dookólnej barbarii rozwinęła się egipska sztuka, kultura, nauka (astronomia, geometria, algebra), pismo, system miar i wag.

Część poświęconą Egiptowi starożytnemu otwierały informacje na temat Nilu, jego źródeł, delty, przepustowości w różnych punktach koryta. Wspaniałym opisom wylewów życiodajnej rzeki towarzyszyły wiadomości o najstarszych pomysłach związanych z budową kanałów nawadniających i rezerwuarów wody (Amenemhata III z XII dynastii, żyjącego w XIX wieku przed Chr.). Dzieje Egiptu zostały ukazane od zarania monarchii, to jest od panowania Menesa (Narmera), założyciela pierwszej dynastii i twórcy państwa „Obydwu Krajów” (w IV tysiącleciu przed Chr., Chojecki lokował go podług ówczesnej chronologii w VI-V tysiącleciu przed Chr.), poprzez czasy Hyksosów („królów pasterzy”), Ramzesa II, okres kolonizacji greckiej (VIII-VI wiek przed Chr.), panowanie perskie (Kambyzes II, syn Cyrusa), rządy Aleksandra Wielkiego, po Egipt ptolemejski i rzymski, aż do ustalenia chrześcijaństwa religią państwową (w $381 \mathrm{r}$.) przez Teodozjusza I Wielkiego ${ }^{98}$. Autor podjął też próbę zsynchronizowania historii biblijnej z dziejami Egiptu, to znaczy ulokowania bohaterów biblijnych (Abrahama, Józefa, Mojżesza) na osi chronologicznej Egiptu (co sprawia archeologom i historykom ogromny kłopot do dziś).

Po zarysie historycznym następował opis najważniejszych zabytków Egiptu starożytnego, wśród których wiele było znalezisk najświeższych, na przykład

\footnotetext{
${ }^{95}$ Egipt dziewiętnastowieczny mimo olbrzymiej powierzchni liczył 5-6 milionów mieszkańców, podczas gdy w czasach inwazji muzułmańskiej zamieszkiwało go aż 15 milionów ludzi i istniało około 10 tysięcy miast. Zob. Ch. EDMOND, L'Égypte a l'exposition universelle, s. 23.

${ }^{96}$ Autor podkreślał, że najstarsze egipskie inskrypcje, będące przejawem poszanowania prawa i człowieka, powstały już cztery tysiące lat przed rewolucją francuską. Zob. Ch. EDMOND, L'Égypte a l'exposition universelle, s. 30-31.

${ }^{97}$ Zob. tamże, s. 29.

${ }^{98}$ Oczywiście Chojecki nie wiedział jeszcze nic o Tutanchamonie z XVIII dynastii.
} 
statua faraona Chefrena z IV dynastii czy freski grobowe odkryte niedawno przez François Mariette'a.

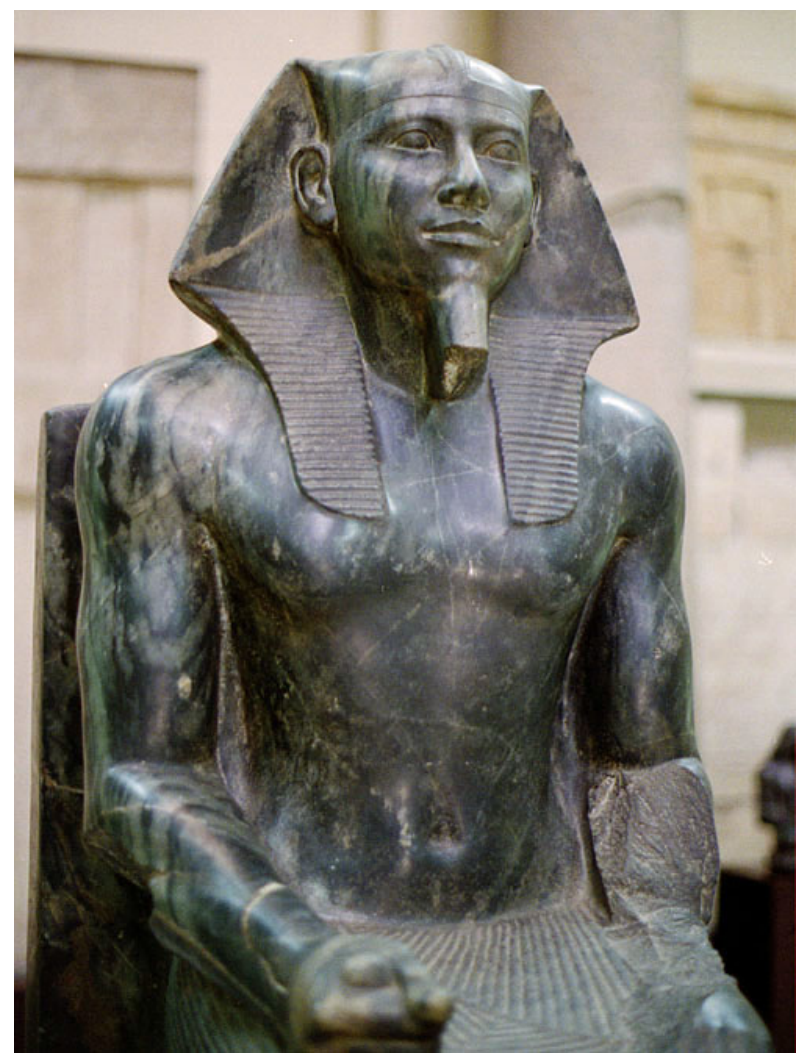

Fot. 2. Statua Chefrena odkryta przez Mariette'a w 1860 r.

Chojecki objaśniał też tajemnice kamienia z Rosetty, który posłużył Champollionowi do odczytania hieroglifów, opisywał ze znawstwem tytaniczną architekturę dwóch metropolii egipskich: Memfis i Teb, dokonując ich ciekawego porównania:

Memfis ma szlachetność, prostą i szczerą wielkość, Teby mają przepych, wielkość wystawną, teatralną. Nawet bogactwa Ludwika XIV bledną przy splendorze Teb ${ }^{99}$.

${ }^{99}$ Ch. Edmond, L'Égypte a l'exposition universelle, s. 61. 
Za dwie dominanty ideowe Egiptu starożytnego uznał tajemnice życia (uosobioną w formie sfinksa) i śmierci (wyrażoną przez piramidy). Egipt faraonów był dla niego przede wszystkim „starym cmentarzyskiem”" ${ }^{100}$. Podobna optyka pojawi się także w Kleopatrze i Cezarze Norwida.

Kolejne akapity poświęcone były wybranym grupom egipskich artefaktów: procesowi wytwarzania papirusu i opisowi zawartości papirusów zgromadzonych przez Mariette'a w muzeum w Bulak; mitologii starożytnego Egiptu oraz architekturze sakralnej (inspirującej później Greków); realistycznemu malarstwu egipskiemu (tu znalazły się drobiazgowe opisy malowideł i dekoracji na stanowiskach badanych przez Mariette'a: m.in. w Deir el-Bahari i Abydos); rzeźbie i jubilerstwu (bransoletki, naramienniki, naszyjniki także pochodziły ze znalezisk Mariette'a, a więc były „oryginałami, które niegdyś cieszyły oczy Egipcjan”101).

Chojecki wymieniał i pokrótce opisywał zaprezentowane w Paryżu statuetki, meble, skrzynie, polichromowane sarkofagi, mumie, toporki i sztylety, zwierciadła, drobne przedmioty kultu, skarabeusze, utensylia, wazy, przedmioty kultu, buteleczki na perfumy, emblematy itp., przedmioty wykonane z brązu, emaliowanego fajansu, porcelany, masy plastycznej, alabastru, porfiru, bazaltu, drewna. Jednak jego celem nie było opisać i ,uparagrafić”; nie katalogował artefaktów w sposób bezduszny; za każdym razem próbował przeniknąc ich intymność, dotrzeć do ukrytego pod powierzchnią, głębokiego sensu, odczytać ich przekaz symboliczny ${ }^{102}$.

Opowieść o wiekach średnich Egiptu została zdominowana przez dwa zagadnienia: rozkwit Aleksandrii (wspaniała biblioteka zawierająca 500 tysięcy zwojów i filozofia aleksandryjska) oraz narodziny islamu. Podrozdział o dziejach muzułmanów był stosunkowo mało samodzielny; stanowił, jak zaznaczał sam autor, wierne streszczenie dzieła Gustava Weila - profesora języków orientalnych na uniwersytecie w Heildelbergu, Geschichte der islamitischen Voelker ${ }^{103}$. W opowieści o rządach i osiągnięciach poszczególnych władców ommajadzkich, abbasydzkich i fatymidzkich, szczególne miejsce przypadło kalifom: Al-Mansu-

\footnotetext{
${ }^{100}$ Tamże, s. 70.

${ }^{101}$ Zob. Tamże, s. 108.

${ }^{102}$ Zob. Tamże, s. 126.

${ }^{103}$ Stąd zapewne obecność arabsko-germańskich komparacji w pracy Chojeckiego. Zob. G. WeIL, Geschichte der islamitischen Voelker, Stuttgart 1866.

Mahomet, łączący szczere przekonanie profety ze zdolnościami politycznymi, a entuzjazm z kalkulacją, wydał się polskiemu autorowi samą kwintesencją swej rasy, która w arabesce spoiła „geometrię imaginacji” z „szaleństwem algebry”. Chojecki - były proudhonista zauważał też, że Arabowie mają temperament „najbardziej anarchiczny na świecie”, Ch. EDMOND, L'Égypte a l'exposition universelle, s. 147.
} 
rowi, za którego nastąpił niebywały rozkwit Bagdadu; Harunowi al-Raszidowi, uwiecznionemu w Księdze tysiąca i jednej nocy, oraz uchodzącemu za uosobienie wschodniego despotyzmu i fanatyzmu Al-Hakimowi, który nakazał zburzyć Bazylikę Grobu Bożego w Jerozolimie.

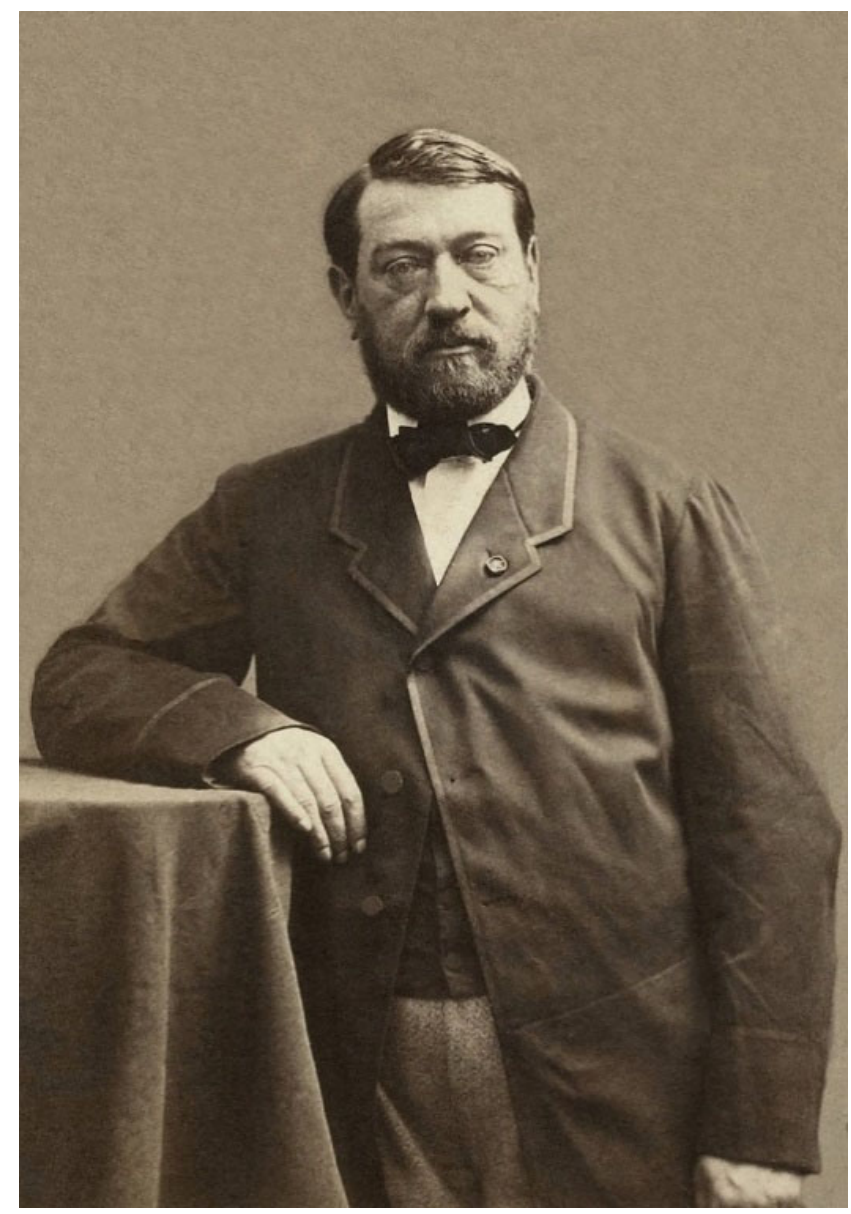

Fot. 3. August Mariette (fot. Nadar, 1861)

Kolejne akapity dzieła dedykowane były sztuce arabskiej: Koranowi i początkom arabskiej poezji, a w dalszej kolejności architekturze (sakralnej - meczet i świeckiej - pałac), wyraźnie naznaczonej przyzwyczajeniami i marzeniami nomadów (zamiłowanie do poruszanych przez wiatr draperii przypominających 
poły namiotu; fontann niosących życiodajną wodę; do kopulastej, a nie płaskiej formy sklepienia, naśladującej kształt niebios; predylekcja do ornamentyki organicznej, czerpanej z natury etc.). Chojecki zatrzymał się dłużej nad formą arabeski, zajmującą bardzo ważne miejsce w romantycznej teorii sztuki, a uważaną za kwintesencję sztuki (i duszy) arabskiej:

Arab włożył całą swą duszę w arabeskę, ma ona duszę pełną ognia, oszałamiającą zapałem religijnym, przyjemną i czarującą; te linie, które się poszukują i uciekają, by się odnaleźć, splatają się i znów się rozdzielają; te żywe kolory, które migoczą rodzajem harmonijnego rytmu, skalkulowany nieład detali i ich wymyślny nieporządek, spokój obecny pośród niepohamowanego ożywienia, wszystkie najbardziej fantastyczne formy świata intymnie złączone, jakby cudem, z regularnymi formami geometrycznymi, szalone marzenie skreślone cyrklem i podług reguł - tak, w tym jest cały ród Mahometa, rasa w najwyższym stopniu aktywna, a przecież tak leniwa, tak skora do zezwalania wyobraźni na błądzenie, a przecież z tak sprytnym rozsądkiem praktycznym ${ }^{104}$.

Zaprezentował też arabską architekturę świecką użyteczności publicznej: karawanseraje, zamki, łaźnie, fontanny publiczne. Jej wspaniałych exemplów dostarczył mu zarówno średniowieczny Kair, jak i mauretańska Hiszpania. Opisy pokazanego w Paryżu wyposażenia pałacu, mebli, broni należącej do Mehmeda Ali, egzemplarzy Koranu, kolekcji inkrustowanych macicą perłową drewnianych meble, broni, talerzy, stali damasceńskiej, waz i rzeźbionych szkatułek (kolekcji przygotowanej przez Meymara) dopełniły obraz całości ${ }^{105}$. Na końcu zamieszczone zostały dane statystyczne dotyczące powierzchni kraju, jego populacji, podziału administracyjnego, dróg, kanałów Nilu, jezior, linii telegraficznych, handlu zagranicznego, transportu i nawigacji, szkolnictwa, finansów, systemu

\footnotetext{
${ }^{104}$ Tamże, s. 180.

${ }^{105}$ Oczywiście nie były to wszystkie tematy poruszane w sprawozdaniu Chojeckiego. Sporo miejsca poświęcił on opisom narzędzi, haftów i biżuterii (filigran srebrny) egipskiej. Wspominał o mieszczącej się na wystawie arabskiej kafejce, o żywych zwierzętach, które mogli oglądać zwiedzający (dwa dromadery i dwa osiołki). Pisał o ogromnym planie-reliefie Egiptu (o powierzchni 45 metrów kwadratowych), przygotowanym przez Figariego oraz zaprezentowanej bibliotece, mieszczącej w szklonych szafach kolekcję ksiąg w języku arabskim i tureckim (aż czterysta dzieł, wśród nich klasyka, dzieła teologiczne, filozoficzne i moralne, literackie, matematyczne, prawne, medyczne, historyczne i podróżnicze, dotyczące przemysłu, rzemiosł, wojskowości i marynarki, administracji, obyczajów). Zwrócił uwagę na ciekawą kolekcję zdjęć współczesnego Egiptu autorstwa kairskiego fotografa Désiré. Następne akapity poświęcone były różnym modelom pisma egipskiego, rasom zamieszkującym Egipt, rolnictwu, zaprezentowanym kolekcjom włókien roślinnych i gatunków drewna, tekstyliów, zbóż i przypraw, henny, miodów, olejków roślinnych, strojów i obuwia, rogów i skór różnych zwierząt i temu podobnych.
} 
miar i wag, systemu monetarnego, kalendarza, sił militarnych. Ostatnim zaś elementem był katalog ekspozycji składający się z dwóch części. W pierwszej znalazły się przedmioty z Egiptu właściwego, podzielone na dziesięć grup, a w ich obrębie na dziewięćdziesiąt pięć klas ${ }^{106}$. Część druga katalogu obejmowała usystematyzowane tematycznie przedmioty pochodzące $\mathrm{z}$ górnego Nilu, Nubii, Sudanu.

Norwid odwiedził udostępnioną publiczności 1 kwietnia 1867 r. paryską Wystawę Światową kilkakrotnie ${ }^{107}$. Był jej niezwykle ciekaw i wracał w uniesieniu, zafascynowany i zainspirowany tym, co zobaczył. Ekspozycja ta zastąpiła mu poniekąd dalekie podróże (na Bliski i Daleki Wschód, do południowej Ameryki itd.) oraz archeologiczne eksploracje, tak upragnione, a nigdy niezrealizowane z braku środków: „Podróżą zowię tę wycieczkę - jakże bo inaczej zwać elipsowy obieg panduli przechodzącej przez wszystkie świata kraje?" (PWsz VI, 203). Wielokrotne wzmianki epistolarne świadczą, że cuda wystawy przez wiele miesięcy żywo zajmowały jego wyobraźnię. Po raz pierwszy napomknął o swych odwiedzinach na Polu Marsowym w liście do kuzyna Michała Kleczkowskiego z 2 maja (,,je revenais à pied de l'Exposition où j'ai passé plusieurs heures sur pieds", PWsz IX, 283). W czerwcu, zapewne po kolejnej wizycie, przesłał Joannie Kuczyńskiej relację z wystawy (Podróż po Wystawie Powszechnej, PWsz VI, 203-208), z cichą nadzieją na zamieszczenie jej przez adresatkę w jakimś krajowym dzienniku (co jednak nigdy nie nastąpiło). O ekspozycji nadmieniał w listach jeszcze kilkakrotnie: Cieszkowskiemu (lipiec, PWsz IX, 298), Kuczyńskiej (sierpień?, PWsz IX, 299), Konstancji Górskiej (ok. 31 sierpnia, PWsz IX, 304),

${ }^{106}$ Były to rozmaite manuskrypty, w tym rękopisy Koranu, a także instrumenty muzyczne, narzędzia medyczne, monety, mapy, meble i wyposażenie wnętrz, dywany, dzieła złotnicze i wykonane z brązu, zegarmistrzostwo, lampy, tkaniny (bawełniane, lniane, jedwabne etc.), hafty i pasmanterie, stroje damskie i męskie, biżuteria, broń, przedmioty podróżne i używane w namiotach, produkty eksploatacji kopalń i metalurgiczne (kolekcja skał i minerałów przygotowana przez Figariego), kolekcja okazów paleontologicznych zgromadzona i przygotowana przez doktora Reila z Kairu (kości i zęby różnych zwierząt prehistorycznych), wyroby kotlarskie, kolekcja różnych gatunków drewna pochodzącego $\mathrm{z}$ drzew rosnących $\mathrm{w}$ dolinie Nilu, wypchane okazy zwierząt, produkty rolne, kolekcja ziaren, korzeni, roślin i krzewów, produkty chemiczne i farmaceutyczne, leki i środki farmaceutyczne, barwniki, skóry, maszyny i narzędzia używane $\mathrm{w}$ różnych dziedzinach produkcji, kolekcja zbóż, różnych gatunków warzyw i owoców, mięs, słodyczy, żywe zwierzęta, wystawa dotycząca szkolnictwa, dzieła drukowane i manuskrypty używane w edukacji w medresach, zbiory fotografii itp.

${ }^{107}$ Norwid z upodobaniem wizytował Wystawy Światowe (por. jego Uwagi o ekspozycjach, PWsz VI, 546-547). Zob. też E. DĄBRowICZ, „Piękno powszechne”. Norwid wobec wystaw światowych, [w:] Piękno wieku dziewiętnastego. Studia i szkice z historii literatury i estetyki, red. E. Nowicka, Z. Przychodniak, Poznań 2008, s. 107-126. 
Bronisławowi Zaleskiemu (ok. 20 października, PW, IX, 311) i ponownie Kuczyńskiej („Niedawno jeden z Poznańskiego na Ekspozycji mi mówił...”, październik/listopad 1867, PWsz IX, 320). Poeta musiał spędzać na Polach Marsowych całe dnie, z pasją oddając się kulturowym studiom i swobodnym przechadzkom, pozwalającym zakosztować atmosfery dalekich miejsc i czasów, musiał być nawet uważany za stałego ich bywalca, skoro ktoś przekazał pytającemu o niego przyjezdnemu ,adres” Norwida ... „na Ekspozycji” (PWsz IX, 304).

Zapewne wielokrotnie spotykał się też w dziale egipskim z Chojeckim (aczkolwiek nie zachowała się jakakolwiek wzmianka na temat tych spotkań i rozmów), a nawet korzystał z jego objaśnień bądź przewodnictwa po tej części wystawy $^{108}$. Przypuszczalnie to właśnie od niego czerpał też różne bezcenne informacje. Dawny przyjaciel wprowadzał go w świat, którym niegdyś, jeszcze w latach warszawskich, oczarował ich obu Władysław Wężyk ${ }^{109}$.

[...] największe bodaj wrażenie - pisał J.W. Gomulicki - wywarł na nim jej dział egipski, urządzony przez Edmunda Chojeckiego, dawnego przyjaciela poety z czasów warszawskich oraz z pierwszego pobytu paryskiego, którego eksponaty - ofiarowane następnie Chojeckiemu przez rząd egipski - odegrały zapewne poważną rolę w ukształtowaniu się późniejszej tragedii Norwida Kleopatra i Cezar (Metryki i objaśnienia, PWsz VII, 552).

Bieda Norwida sprawiła, że jego wiedza o Egipcie musiała pochodzić z drugiej ręki, głównie z lektur, ale wystawione w Paryżu bezcenne oryginały z muzeum w Bulak i innych wspaniałych zbiorów, pozwoliły mu zetknąc się z Egiptem faraonów autentycznym: zakosztować jego atmosfery, poczuć nawet zapach artefaktów sprzed tysięcy lat. Bezpośredniość tego doświadczenia przełożyła się na prawdziwość i sugestywność egipskich realiów ukazanych w Norwidowskim dramacie o królowej Egiptu.

${ }^{108}$ Osobą, która odegrała ważną rolę we wtajemniczaniu Norwida w tematykę egipską (i dostarczała poecie różnych drobnych zabytków egipskich), był też Mieczysław Geniusz, którego szwagier pracował przy budowie Kanału Sueskiego (w końcu i sam Geniusz wyjechał do Egiptu). O rękopisach Norwida znajdujących się w posiadaniu M. Geniusza zob. T. SMOLEŃSKI, Egipskie norwidiana, „Ateneum Polskie” 2(1908), nr 1, s. 105-115.

${ }^{109}$ Wizytujący ekspozycję egipską mieli okazję doświadczać przeżyć niebywałych. Paryski korespondent „Dziennika Poznańskiego” w swym liście z 3 lipca opisuje wydarzenie sprzed kilku dni (któremu przyglądał się sam cesarz Francji z rodziną, wicekról Egiptu oraz wiele rodzin książęcych), mianowicie publiczne otwarcie mumii wydobytej niedawno z grobowca. Dostojni goście przyjmowani byli przez Mariette'a i Edmunda Chojeckiego. Zob. J.S., Listy z wystawy paryskiej, „Dziennik Poznański” 1867, nr 157, s. 2. 
W reportażowym „dagerotypie” przesłanym Kuczyńskiej poeta opisał skonstruowaną na wystawie wierną kopię egipskiej świątyni, wypełnioną jednak żywymi barwami świeżych jeszcze dekoracji:

Ale oto znana mi granitowa brama Świątyni egipskiej starożytnej - tę przeszedłszy, wchodzisz w dwurzęd leżących sfinksów, tam i owdzie wachlarzowatymi palmami przetykanych dalej schody świątyni sfinksowymi dokoła kolumnami z czterech stron otoczonej. Cała ta świątynia zewnątrz i wewnątrz pstra jest hieroglifami, które zwykle widywaliśmy starte i spłowiałe - i czyni to widok szczególniejszy - albowiem mądrość linii ogólnych i powaga wielka całokształtu popstrzone są jaskrawo i tak wszechstronnie, że domyślam się, iż trzy tysiące lat temu, kiedy hieroglifów barwy świeżymi były, to musiał jedynie ogromny wymiar samejże budowy łagodzić tę pstrociznę. Ale wnijdę w kurytarz owych sfinksowych kolumn i obejdę cztery jego ościenia, zwłaszcza iż widzę, że sam będę tą maleńką bawił się przechadzką - niestety, u kąta jednej bazy spostrzegam leżące w cieniu dwie palety kolorów świeżych pełne i zgarnięte pęzle!... tak dalece nie Faraońskich sięgają czasów te igrające w słońcu hieroglify... Zeszedłem przeto schodami w aleję sfinksów i odpoczęło oko moje na cieniach palm wachlarzowych, układających się na piasek. Cóż piękniejszego jest od tych gwiaździstych cieni liścia wachlarzowego, a poruszanego lekkim wiatrem - muskają tak piasek, i kładą się nań gwiazdami przezroczystymi, i milczą... Mało rzeczy piękniejszych widziałem dziś!... a jednakże dziś wszystko widziałem. (Podróż po Wystawie Powszechnej, PWsz VI, 206)

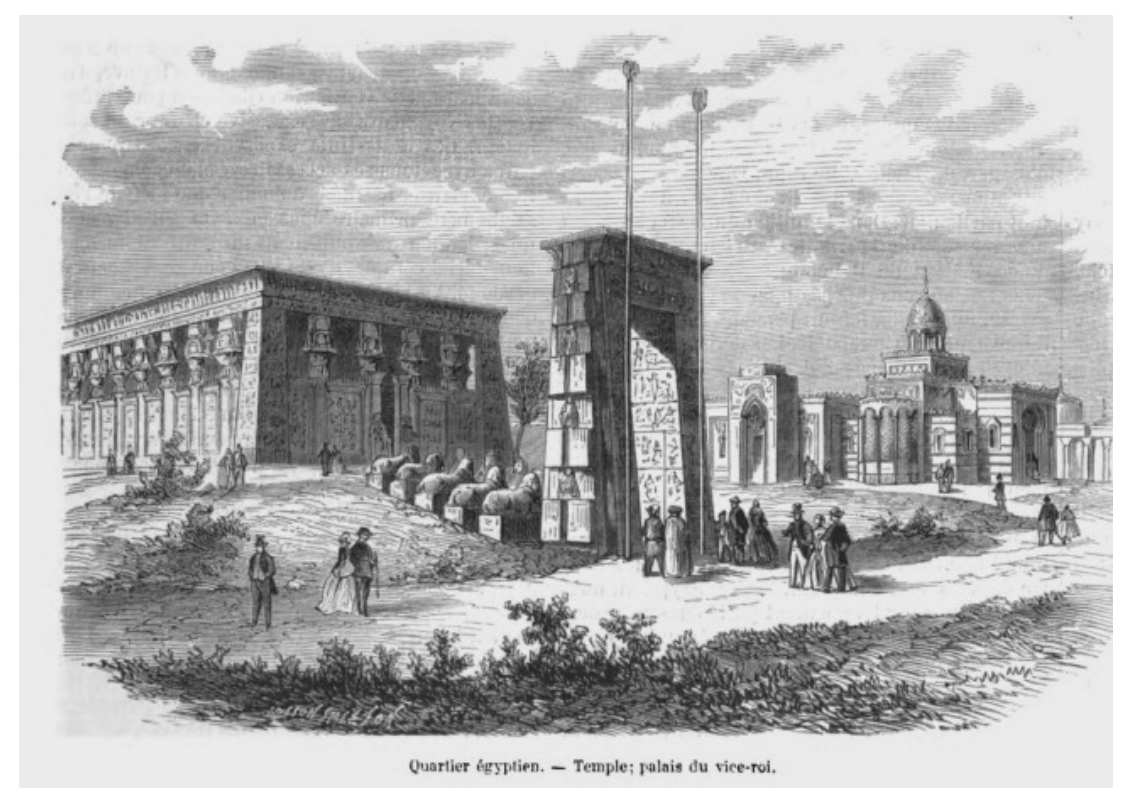

Il. 2. Świątynia egipska (a w oddali pałac wicekróla Egiptu - Selamlik) na Wystawie Światowej w Paryżu w 1867 („L'Illustration” z 30 marca 1867, s. 200) 
Na wzmiankę o świątyni prezentowanej na Wystawie Światowej oraz jej egipskim pierwowzorze (świątynia Izydy na wyspie File) natrafimy w Norwidowskich Notatkach z mitologii ${ }^{110}$ :

Na Ekspozycji 1867 świątynia niesłusznie zwana Temple d’Edfou (kopia z Philae [w edycji PWsz błędny zapis: Philoc. - R.G.-S.]: pylon [rysunek] - kapitele kwiatu lotosowego [w edycji PWsz zapis: lotusowego - R. G.-S.] - muralne malowania w korytarzu zewnętrznym z czasów Mojżesza (wojna 1500 przed Chr. przez królową Hatasu przeciw mieszkańcom Puntu) - w środku najstarsze modele sztuki egipskiej, i te najświetniejsze.

Posągi kamienne Chefren [w PWsz tekst zapisany kursywą, u Norwida podkreślony R.G.-S.] fond et drugiej piramidy, a drewniane najstarsze. Co do ozdób niewieścich, te z mumii królowej Aah-Hopet, spółczesnej Józefowi (Notatki z mitologii k. 18 verso) ${ }^{111}$.

W części starożytnej Norwid mógł również zobaczyć kopię odkrytego (czy raczej „odczytanego”) niedawno przez Mariette'a sześciometrowego reliefowego wizerunku królowej Kleopatry ze ściany świątyni w Denderze, wizerunku będącego wówczas jedyną znaną podobizną egipskiej królowej ${ }^{112}$. Przeżycie to odegrało zapewne ważną rolę w kształtowaniu wyobraźni przyszłego autora Kleopatry i Cezara ${ }^{113}$.

${ }^{110}$ Cytowana notatka Norwida powstała zatem w trakcie trwania Ekspozycji Światowej albo tuż po jej zakończeniu.

${ }^{111}$ Norwid mógł czerpać wiadomości o architekturze starożytnego Egiptu m.in. z dzieła A. Quatremère'a de Quincy, De l'architecture égyptienne considérée dans son origine, ses principes et son gôut, et comparée sous les mêmes rapports à l'architecture grecque, Paris 1803.

${ }^{112}$ Zob. Z. TrojanowiczowA, E. LiJeWSKA, Kalendarz, s. 307.

${ }^{113}$ Zob. też E. ŻWIRKOwSKA, Tragedia kultur. Studium o tragedii historycznej C. K. Norwida „,Kleopatra i Cezar”, Lublin 1991; E. ŻWIRKOWSKA, Jeszcze o egipskiej tragedii Cypriana Norwida, „Studia Norwidiana” 12-13: 994-1995), s. 243-261; L. KAMIENIECKI, Numizmatyczna geneza „Kleopatry” Norwida, „Biuletyn Numizmatyczny” 1968, nr 34, s. 651. 


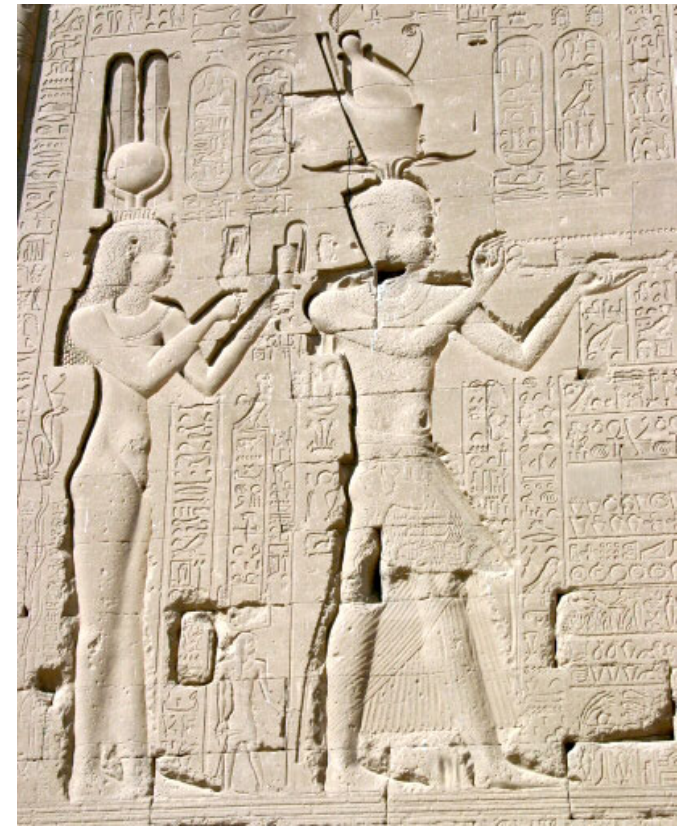

Fot. 4. Relief ze ściany świątyni bogini Hathor w Denderze przedstawiający Kleopatrę i Cezariona

Jednak nie tylko to dramatyczne dzieło Norwida zawdzięcza swój kształt wystawie paryskiej. Również Norwidowski Album Orbis (I) wzbogacił się pod wpływem tych doświadczeń o obfity „dział egipski”. Znajdujące się tam szkice i rysunki Norwida były często odwzorowaniem (choć zdarzały się oczywiście i modyfikacje ${ }^{114}$ ) autentycznych fresków zaprezentowanych w Paryżu (tam w formie wiernych kopii): z Qurna, Beni-Hassan, Karnaku i Teb. Świadczą o tym wskazujące na pochodzenie malowideł adnotacje autora na rysunkach („W Gurnah i Beni Hassan” przy rys. 76; Egipski Harfiarz „Z rysunku w Tebach” rys. 79; „Z egipskich fresków w Gournah” rys. 88 itd., PWsz XI, 527-528) oraz ich datowanie w sygnaturach (datą 1867 opatrzony jest rysunek o numerze 75 : C. Norwid 1867, PWsz XI, $527^{115}$ ).

\footnotetext{
${ }^{114} \mathrm{Na}$ przykład pod rysunkiem 87 przedstawiającym profile kobiet egipskich Norwid dopisał: „Egipskie z profile Karnaku i w Tebach - z odmianą tą, że oczy tam nie są w profilach” (PWsz XI, 528).

${ }^{115}$ Oczywiście są w owym zbiorze także rysunki z lat wcześniejszych: pięćdziesiątych i sześćdziesiątych, wiele dat jest też nieczytelnych.
} 
RENATA GADAMSKA-SERAFIN

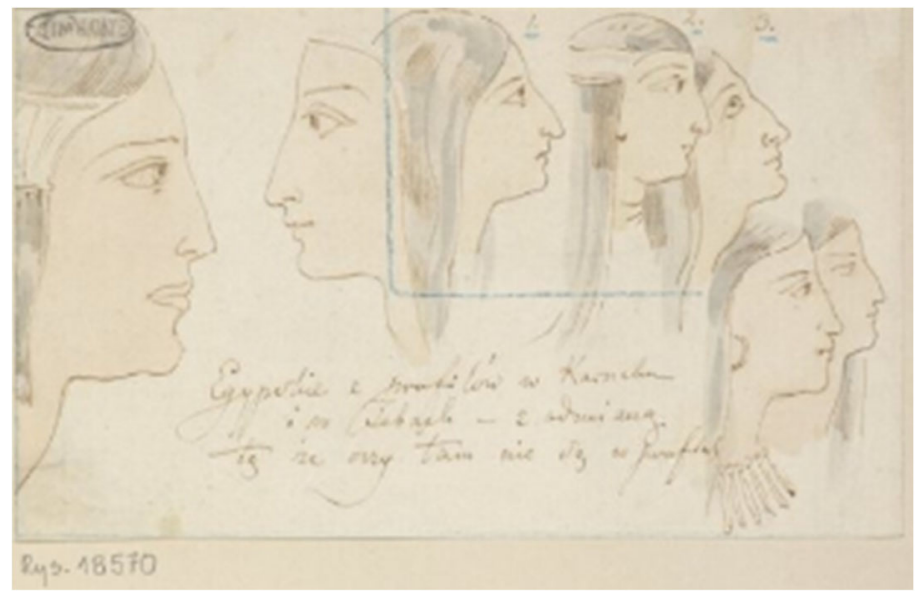

Rys. 1. C. Norwid, Profile kobiet egipskich (z adnotacją autora: „Egipskie profile z Karnaku i w Tebach - z odmianą tą, że oczy tam nie są w profilach"), Album Orbis (I) rys. 87, k. 83

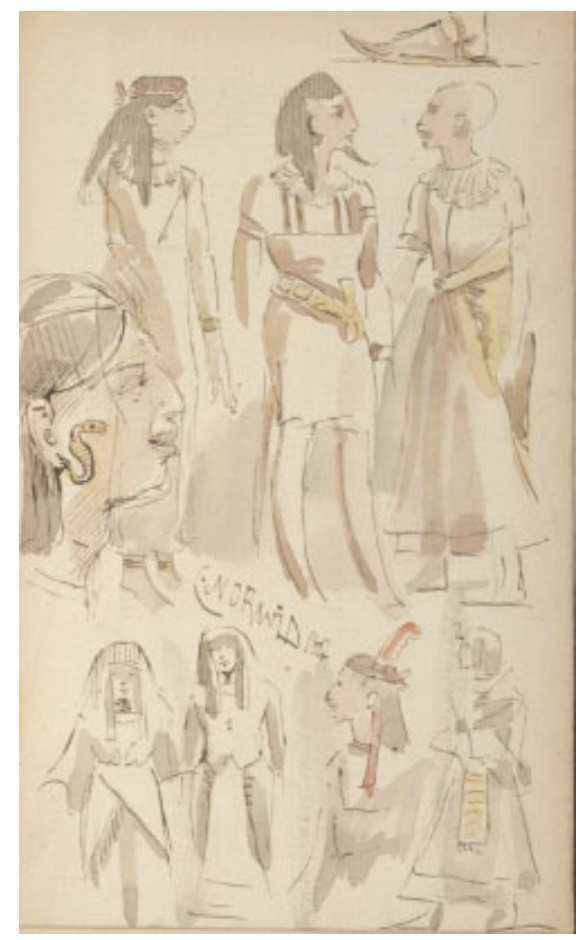

Rys. 2. C. Norwid, Rysunki egipskie (sygnatura: C. Norwid 1867), Album Orbis (I) rys. 75 , k. 74 
Uwagę Norwida przykuły nie tylko egipskie starożytności, ale i mieszczące się w części „Egipt współczesny” (to jest w Okelu) warsztaty arabskich rzemieślników: uwijający się $\mathrm{w}$ nich ludzie o egzotycznych, śniadych twarzach (tkacze, złotnicy, wytwórcy mat), ich narzędzia i piękne wyroby. Nieopodal, na tyłach karawanseraju, znajdowała się niewielka stajnia, której mieszkaniec „królewski-wielbłąd-biały” "wywołał w poecie głęboką refleksję historiozoficzno-archeologiczną:

Uczułem we krwi mojej owy atom patriarchalnej-wszech-ojczyzny, którego tysiące lat nie starły w człeku! (PWsz VI, 207).

W pobliżu Okelu funkcjonowała także opisywana przez Chojeckiego i chętnie odwiedzana przez paryską publiczność arabska kawiarnia ${ }^{117}$. Norwid spisał swą Podróż po Wystawie Powszechnej w innym miejscu tego typu, mianowicie w kafejce znajdującej się przy pałacu beja Tunezji1 ${ }^{118}$, w której kosztował oryginalnego smaku tłustawej kawy, przyrządzanej na sposób wschodni (długo gotowanej ze świeżo miażdżonych ziaren).

${ }^{116}$ Był to zapewne ten sam biały wielbłąd, o którym pisał do „Dziennika Poznańskiego” jego paryski korespondent: „Egipt także świetniej w parku wystawy jest przedstawiony aniżeli w samym gmachu. Niedaleko świątyni z epoki faraonów [...] wznosi się budowa w stylu orientalnym, hieroglifami upstrzona, podparta na ciężkich kolumnach, pomalowanych w żywe kolory, a ozdobionych liściem i kwiatami lotosu. Skoro w dzień gorący wejdzie się do środkowej sali, oświeconej przez dach szklany, to słońce, prosto w szyby uderzające, może niejednemu dać wyobrażenie o durzących afrykańskich upałach; wielbłąd z wężową szyją o białych kudłach, stojący u wejścia, dopomaga złudzeniu i miejscowego kolorytu dodaje”. J.S., Listy z wystawy paryskiej, „Dziennik Poznański” 1867, nr 197, s. 2.

${ }^{117}$ Zob. też Exposition Universelle de Paris 1867. Okel (Okala). https://www.worldfairs. info/expopavillondetails.php?expo_id=3\&pavillon_id=3756 (dostęp: 20.11.2018):

„Przed Okelem znajdowała się duża arabska kawiarnia, taka jak w Kairze i innych miastach Egiptu. Kawę pije się na Wschodzie wszędzie: ale do tych miejsc przychodzi się palić fajkę wodną, grać w warcaby lub szachy, słuchać miłego gawędziarza lub znaleźć przyjaciół”.

${ }^{118}$ Usługująca we wnętrzu dziewczyna, ,w kwefie na włosach i z naramiennikami złotymi” zdała się poecie, niezmiennie patrzącemu na teraźniejszość „,Z wysokości dziejów”, „niesłychanie do Kleopatry podobna”: „Całą archeologię-profilów czytam na tej twarzy i w tych ramionach i gestach..." (PWsz VI, 208). 


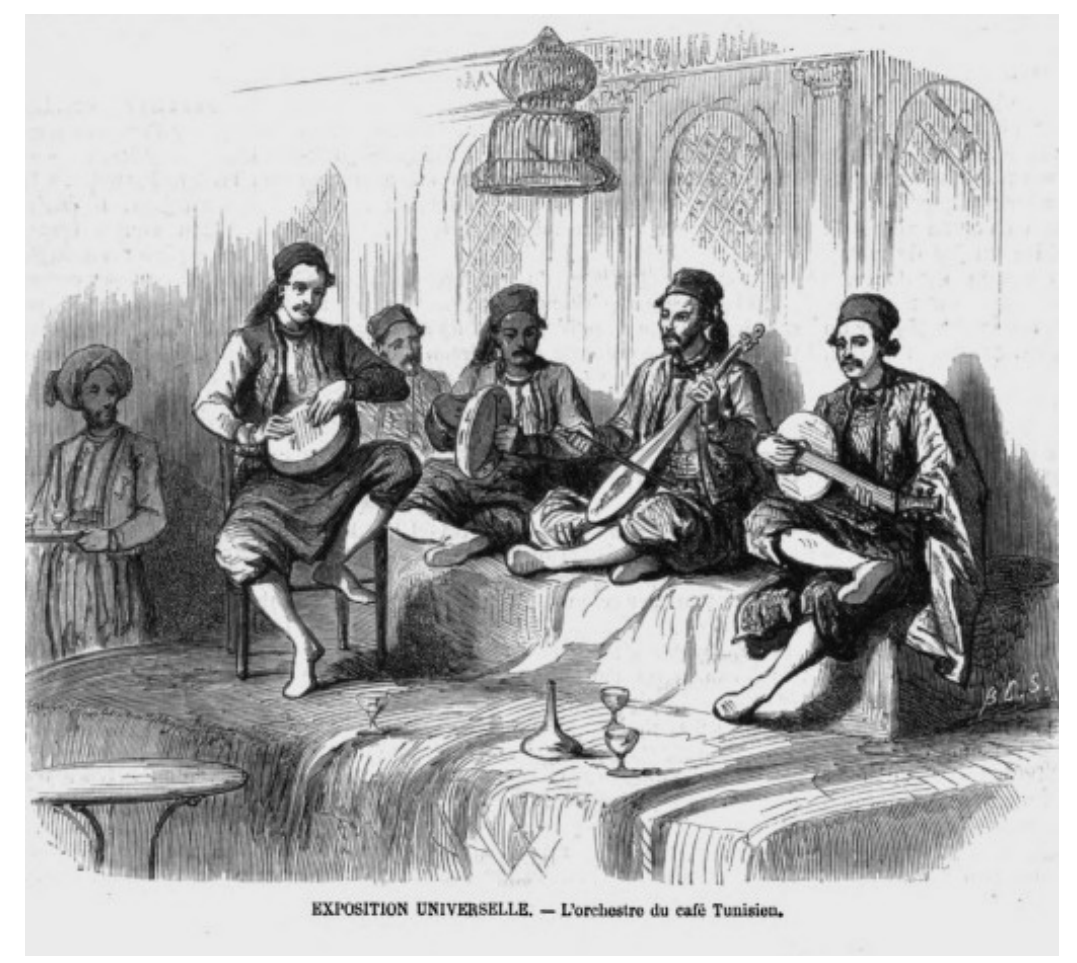

Il. 3. Orkiestra w kawiarni tunezyjskiej („L'Illustration” z 27 kwietnia 1867 r., s. 260)

Kontakty Norwida z Chojeckim nie urwały się po zakończeniu wystawy paryskiej. W roku 1869 Cyprian poprosił listownie Charlesa Edmonda (list zaginiony) o jego zaangażowanie w prace emigracyjnego Stowarzyszenia Pomocy Naukowej. Ten początkowo odmówił, thumacząc się „brakiem możebności” i „reumatyzmem w nodze" (List E. Chojeckiego do Norwida z 3 maja 1869 r. ${ }^{119}$ ), jednak w styczniu 1870 wygłosił pro publico bono prelekcję Patriotyzm i objawy jego u niektórych narodów w ramach Konferencji Polskich odbywających się w Sali Wielkiego Wschodu Wolnomularskiego ${ }^{120}$. Prawdopodobnie to Chojecki przedstawił Norwida (,przed wojną”, to jest rokiem 1870) księżnej Matyldzie Bonaparte, siostrze księcia „Plon Plon” - protektorce pisarzy i arty-

${ }^{119}$ Zob. Z. TrojanowiczowA, E. LiJewSKA, Kalendarz, s. 395 oraz Ch. EDMond, Correspondances.

${ }^{120} \mathrm{~W}$ tym samym roku, we wrześniu, Z. Węgierska prosiła Norwida o przesłanie Chojeckiemu zaproszenia od redaktora „Gazety Polskiej” Józefa Sikorskiego (nie znała bowiem adresu Chojeckiego). Zob. Z. TrojanowiczowA, E. LiJewSKA, Kalendarz, s. 421. 
stów (m.in. Teofila Gautier), która obiecała zakupić od poety cenny rysunek Leonarda (PWsz X, 99).

Dalsze losy Norwida i Chojeckiego potoczyły się jednak dwoma różnymi torami. Charles Edmond należał do nielicznego grona polskich emigrantów, którzy mimo niewątpliwych trudności odnaleźli się w wygnańczej rzeczywistości, a nawet całkiem nieźle w niej prosperowali:

Osiadłszy we Francji, korzystał z godnej pensji urzędnika Senatu (włącznie z mieszkaniem służbowym), miał więc dość pieniędzy na życie, i to dość wygodne. Dzięki wystawie powszechnej w roku 1867, podczas której jego zaangażowanie zostało hojnie wynagrodzone przez wicekróla Egiptu, mógł sobie wystawić dworek w Bellevue, którego tak bardzo zazdrościli mu Goncourtowie. Liczni byli zresztą biesiadnicy, którzy zasiadali przy tamtejszym stole. Podczas oblężenia Paryża dom został splądrowany i ograbiony. Prawdą jest, że koszt naprawy domu oraz czasowa utrata pracy w Senacie sprawiły, że Charles Edmond i jego rodzina doświadczali przez kilka kolejnych lat kłopotów finansowych. [...] wybrał pracę w administracji jako... źródło zarobku i gwarancję bezpieczeństwa ${ }^{121}$.

Przyjaźń Chojeckiego z kontrowersyjnym księciem Napoleonem i gwarantowana przez nią protekcja trwały aż do roku 1870 .

Nawet po upadku Napoleona Charles Edmond powrócił na swe stanowisko w Senacie. Odradzająca się władza zawsze mogła na niego liczyćc ${ }^{122}$.

Droga Norwida zmierzała tymczasem nieuchronnie w stronę przytułku św. Kazimierza w Ivry.

Relacje Norwida z Chojeckim musiały być w latach siedemdziesiątych już znacznie luźniejsze ${ }^{123}$, skoro Mieczysław Geniusz, wspominający swe pierwsze spotkanie z poetą w roku 1873, pisał: „z opowiadań jego [Norwida - R. G.-S.] wiem, że był niegdyś [podkreśl. R. G.-S.] w ścisłej zażyłości z Edmundem Chojeckim (Charles Edmond) ${ }^{124,}$.

Trzy lata później (w roku 1876), doszczętnie skołatany życiem i osamotniony, Norwid zwrócił się jeszcze listownie do Chojeckiego z prośbą o pomoc (list nieznany), prawdopodobnie w zdobyciu środków na wyjazd do Italii od kogoś

${ }^{121}$ E. DeSURVIRE, Francuska twórczość teatralna Charles 'a Edmonda, s. 78.

${ }^{122}$ Tamże, s. 78.

${ }^{123}$ W 1871 r. Norwid zamieścił swoją proklamację w dzienniku „Temps” (z 21 kwietnia) zapewne dzięki protekcji Chojeckiego (zob. PWsz IX, 648).

${ }^{124}$ List M. Geniusza do Z. Przesmyckiego. Claix, 16 X 1902. Rkps BN IV 6319, k. 111112. Cyt za: Z. Trojanowiczowa, E. LiJewSKA, Kalendarz, s. 552. 
z polskich arystokratów (Branickiego?) ${ }^{125}$. Chojecki odesłał go wówczas wprost do Branickich, thumacząc:

Po strasznych wypadkach oblężenia Paryża, podczas których na chwilę nie opuściłem stolicy francuskiej, gdy wszystko się uspokoiło, arystokracja polska znowu pojawiła się na bruku paryskim. Między tą arystokracją liczyłem kilku dobrych znajomych, wielu dawnych przyjaciół. Żaden z nich po powrocie do Paryża nie zapytał się nawet, co ze mną się dzieje, czyli żyw jestem lub martwy. Zawnioskowałem, że panowie ci, którzy inaczej byliby się obeszli z zostawionym przez nich psem, uznali za rzecz przyzwoitą zupełnie o mnie zapomnieć. Nie biorę im tego za złe. [...] Z mojej strony postanowiłem również nad moimi uczuciami zapanować i od tej chwili zupełnie zerwałem z tym polskim światem. Nie znam i nie chcę znać nikogo, nie widuję żadnego z tych wielmożników ${ }^{126}$.

Cytowana odpowiedź Chojeckiego z 1 grudnia 1876 r. stanowi ostatni korespondencyjny ślad jego kontaktów $\mathrm{z}$ Norwidem ${ }^{127}$. Być może urwały się one całkowicie $\mathrm{w}$ chwili znalezienia się Cypriana w podparyskim przytułku. Czy Chojecki kiedykolwiek odwiedził tam starego przyjaciela? Może zrobił to, składając wizytę zbankrutowanej hrabinie Laurze Czosnowskiej (matce swej córki Marii Chojeckiej), która ponoć zakończyła życie w tym samym Domu św. Kazimierza $^{128}$ ? Czy próbował pomagać również Norwidowi? ${ }^{129}$ Niestety nie zacho-

${ }^{125}$ Zob. Z. TrojanOwiczowa, E. LiJewsKA, Kalendarz, s. 632-633.

${ }^{126}$ Ch. EDMOnd, Correspondances, s. 186.

${ }^{127}$ Już po śmierci L. Czosnowskiej, latem roku 1881, Norwid pisał o losie jej dzieci do K. Górskiej (,córka jest w zakonie w Sedan, a syn oficerem kawalerii francuskiej” (PWsz X, 155).

${ }^{128}$ E. Desurvire wysunął przypuszczenie, że Chojecki nie pozostał obojętny na dramatyczny los kobiety, którą kiedyś kochał: „Możemy [...] przypuszczać, że Chojecki próbował jej pomagać w ostatnich latach jej życia, choć brak nam dokumentów, które w jednoznaczny sposób potwierdzałyby te intuicje" (La comtesse Laura Czosnowska, s. 230). Na temat pensjonariuszy domu św. Kazimierza zob.: J. SzCZEPAŃSKI, Weterani powstań narodowych w Zaktadzie św. Kazimierza w Paryżu, Warszawa 2011; M. CZAPSKA, Miłosierdzie na miarę klęsk, Londyn 1954; A. SysKi, Zakład Św. Kazimierza w Paryżu. Szkic historyczny, Łuck 1936; E. LIJEWSKA, Zakon rycerski czy „kolonia karna”? Norwid w Domu św. Kazimierza, [w:] Biografie romantycznych poetów, red. Z. Trojanowiczowa, J. Borowczyk, Poznań 2007, s. $277-285$.

${ }^{129}$ Odmowa, z jaką spotkał się Norwid w roku 1876, nasuwa wniosek, że było jednak inaczej. W roku 1880 Hipolit Skimborowicz, wspominając Norwida i Chojeckiego z lat warszawskich, pisał następująco o ich aktualnym położeniu: „Jeden [Chojecki] od lat bawiąc za granicą zmienił nazwisko, pisze tylko po francusku i zaniechał mowy ojczystej. Drugi [Norwid], tamże siedząc, ogłuchł i zapadł na chorobę oczów [...]”, Gabriela i entuzjastki, „Bluszcz”, nr 18 (5 V 1880). 
wał się żaden ślad, który wskazywałby na to, że Charles Edmond nie zapomniał o swym dawnym, oddanym przyjacielu gasnącym u sióstr szarytek w Ivry.

\section{BIBLIOGRAFIA}

CARR E.H., The Romantic Exiles: a Nineteenth Century Portrait Gallery, London 1933.

ÇELIK Z., Displaying the Orient: Architecture of Islam at Nineteenth-Century World's Fairs. Berkeley-Los Angeles-Oxford 1992.

ChaPlain J., [Nota o ksiażce:] Emmanuel Desurvire „Karol Edmund Chojecki, polski patriota, odkrywca, żotnierz, dramaturg, powieściopisarz, publicysta, bibliotekarz...”. „Studia Polonistyczne" 49(2014), s. 223-225.

Charles E., Correspondance, oprac. E. Desurvire, Paris 2014.

Charles E., Voyage dans les mers du Nord à bord de la corvette La Reine Hortense, Paris 1857.

CHOJeCKi A., Chojecki Edmund Franciszek Maurycy, [w:] Polski Stownik Biograficzny, t. III, red. J. Brożek, F. Chwalczewski, Kraków 1937, s. 391-392.

CZAPSKA M., Mitosierdzie na miarę klęsk, Londyn 1954.

CZARnOMORSKA J., Norwidiana w korespondencji Marii Trębickiej, „Studia Norwidiana” 9-10: 1991-1992, s. 133-163.

CZARTKOwski A., Cyprian Norwid a Ksawery Branicki, „Kurier Warszawski” 113(1933), nr 140, s. 4-6.

DĄBROWICZ E., ,,Piękno powszechne”. Norwid wobec wystaw światowych, [w:] Piękno wieku dziewiętnastego. Studia i szkice z historii literatury i estetyki, red. E. Nowicka, Z. Przychodniak, Poznań 2008, s. 107-126.

Desurvire E., Charles Edmond Chojecki. L'Oeuvre et la Vie, Saint-Escobille 2014.

Desurvire E., Charles Edmond Chojecki. Patriote polonais, explorateur, soldat, poète, dramaturge, romansier, journaliste, bibliothécaire, t. I-VI, Saint-Escobille 2011-2014.

Desurvire E., Francuska twórczość teatralna Charles'a Edmonda, przeł. P. Śniedziewski, „Prace Polonistyczne” 70(2015), s. 51-80.

Rozdział 1 DesUrvire E., La comtesse Laura Czosnowska ou le malheureux destin d'une lionne. „Studia Norwidiana” 32(2014), s. 207-231.

Exposition universelle de 1867 à Paris. Documents iconographiques, Paris 2008.

Rozdział 2 FALEŃSKI F., Wspomnienia z mojego życia, oprac. J. Rudnicka, „Archiwum Literackie. Miscellanea z pogranicza XIX i XX wieku”, Wrocław-Warszawa-Kraków 1964.

Flaubert et Charles Edmond, leur correspondance (1857-1877), oprac. Z. Markiewicz, Paris 1967.

J.S., Listy z wystawy paryskiej, „Dziennik Poznański” 1867.

JANION M., Skald jako poeta romantyczny, [w:] Zwierciadła pótnocy: związki i paralele literatur polskiej i skandynawskiej, t. I, red. M. Janion, N. Åke Nilsson, A. Sobolewska, Warszawa 1991. 
KAMIONKA-STRASZAK J., „Barbarzyński” heroizm i tkliwa melancholia. Literatura skandynawska $w$ polskich almanachach dobry romantyzmu, [w:] Zwierciadła pótnocy. Zwiazki i paralele literatur polskiej $i$ skandynawskiej, t. I, red. M. Janion, N. Åke Nilsson, A. Sobolewska, Warszawa 1991, s. 60-87.

KASPERSKI E., Dyskursy romantyków. Norwid i inni, Warszawa 2003.

LIJEwSKA E., O dwóch Quidamach. Norwid - Kierkegaard, [w:] „,Quidam”. Studia o poemacie, red. P. Chlebowski, Lublin 2011, s. 256-257.

LiJewsKa E., Profetyczny ironista na przełomie epok, „Roczniki Kulturoznawcze” 7(2016), nr 3, s. 81-98.

LIJEWSKA E., Zakon rycerski czy „,kolonia karna”? Norwid w Domu św. Kazimierza, [w:] Biografie romantycznych poetów, red. Z. Trojanowiczowa, J. Borowczyk, Poznań 2007, s. $277-285$.

MARIETTE A., ,Document”. Communications on the Egyptian Exhibition of 1867 (Murassallat bi khousus maarad al Masri li aam 1867), Cairo 1866.

MARIETte A., Exposition universelle de 1867. Description du Parc egyptien, Paris 1867.

MARIETTE A., Karnak, étude topographique et archéologique, Paris 1858.

MARKIEwICZ Z., Charles Edmond - voyageur et comparatiste oublié, [w:] Études de littérature étrangère et comparée. Connaissance de l'étranger, Paris 1964, s. 292-300.

Markiewicz Z., Charles Edmond Chojecki collaborateur de Sainte-Beuve, [w:] Mélanges de Littérature Comparée et de Philologie, Warszawa 1967, s. 337-343.

Markiewicz Z., Charles Edmond Chojecki et son activité dans le camp des démocrates (1847-1899), „Acta Poloniae Historica” 37(1978), s. 163-174.

MARKIEWICZ Z., Charles Edmond Chojecki intermédiare entre le monde slave et la France, „Canadian Slavonic Papers” 9(1967), nr 1, s. 122-130.

MARKIEWICZ Z., La servitude sans grandeur d'un écrivain bilingue (Ch. Edmond Chojecki), [w:] Actes du VIè Congrès de l'Association Internationale de Littérature Comparée, La Hague-Paris 1966.

MARKIEWICZ Z., Les relations de Charles Edmond avec Herzen et les émigrés (1849-1867), „Annali dell'Istituto Universitario Orientale. Sezione Slava”7(1964), s. 127-136.

NIEWCZAS Ł., Norwid - Branicki - Matejko - Berezowski, „Studia Norwidiana” 34: 2016, S. 125-138.

NouR A., Egyptian-French Cultural Encounters at the Paris Exposition Universelle of 1867.

PiotrowsKi B., Edmunda Chojeckiego wyprawa na Islandię w 1856 r. [Seria „Materiały o Islandii”, z. 53], Warszawa 1982.

Podróże i podróżopisarstwo w polskiej literaturze i kulturze XIX wieku. Studia i szkice, red. A. Kowalczyk, A. Kwiatek, Kraków 2015.

QuATREMERE DE QUINCY A., De l'architecture égyptienne considérée dans son origine, ses principes et son gôut, et comparée sous les mêmes rapports à l'architecture grecque, Paris 1803.

SKRODZKI E., Wieczory piatkowe i inne gawędy, wstęp i oprac. M. Opałek, Warszawa 1962.

SŁABCZYŃSCY W. i T., Stownik podróżników polskich, Warszawa 1992.

SŁABCZYŃSKI T., Stownik polskich podróżników i odkrywców, Warszawa 2017.

SMOLEŃSKI T., Egipskie norwidiana, „Ateneum Polskie” 2(1908), nr 1, s. 105-115. 
SySKI A., Zakład Św. Kazimierza w Paryżu. Szkic historyczny, Łuck 1936.

SzCZEPAŃSKI J., Weterani powstań narodowych w Zakładzie św. Kazimierza w Paryżu, Warszawa 2011.

Trojanowiczowa Z., Dambek Z., Kalendarz życia i twórczości Cypriana Norwida, t. I: 1821 1860, Poznań 2007.

Trojanowiczowa Z., LiJewska E., Kalendarz życia i twórczości Cypriana Norwida, t. II: 1861-1883, Poznań 2007.

VETTER D., Islandia albo krótkie opisanie wyspy Islandyji, oprac. D. Rott, Katowice 1997.

WESTERMARK K., Między wyobrażonym a realnym końcem świata. Islandia $w$,,Voyage dans les mers du nord" Edmunda Chojeckiego, [w:] Romantycy na krańcach świata. Podróże egzotyczne i peregrynacje wewnętrzne, red. E. Modzelewska, P. Sobol, Kraków 2015, s. 63-76, http://www.akademicka.pl/ebooks/free/9c0f2c234805e35b70d546f0cb05e3c2.pdf (dostęp: 20.11. 2018).

WĘżYK W., Podróże po starożytnym świecie, oprac. L. Kukulski, Warszawa 1957.

ŻWIRKowsKa E., Jeszcze o egipskiej tragedii Cypriana Norwida, „Studia Norwidiana” 12-13(1994-1995), s. 243-261.

ŻWIRKowska E., Tragedia kultur. Studium o tragedii historycznej C. K. Norwida „Kleopatra i Cezar”, Lublin 1991.

\section{NORWID I EDMUND CHOJECKI-PODRÓŻNIK}

S t r e s z c z e n i e

Jedną z ważniejszych osób w gronie znajomych Norwida, już w latach warszawskich, a później paryskich, był pisarz Edmund Chojecki (Charles Edmond). Ich przyjaźń zawiązała się w Warszawie w latach czterdziestych XIX wieku i trwała przez całe życie (przynajmniej do lat siedemdziesiątych), choć jej zachowane ślady epistolarne są nieliczne. Przedmiotem szkicu są relacje podróżnicze Chojeckiego i ich inspirujący wpływ na Norwida: wycieczka Edmunda $\mathrm{z}$ hr. Branickim na Krym (Wspomnienia z podróży po Krymie, Warszawa 1845), podróż do mórz północnych z ks. Napoleonem (Voyage dans les mers du Nord, Paris 1857), pobyt Chojeckiego w Egipcie na przełomie lat 1850/1851 i wreszcie jego udział w organizacji ekspozycji egipskiej (w charakterze komisarza generalnego) na Wystawie Światowej w Paryżu w roku 1867 (L'Égypte à l'Exposition universelle de 1867, Paris 1867). Najważniejszym owocem tej inspiracji jest dramat Kleopatra i Cezar Norwida oraz jego zbiór rysunków egipskich w Albumie Orbis (I).

Słowa kluczowe: Cyprian Norwid; Edmund Chojecki (Charles Edmond); podróże romantyków; przyjaźnie Norwida; Kleopatra i Cezar; Wystawa Światowa w Paryżu 1867; Orient romantyków. 


\title{
NORWID AND EDMUND CHOJECKI - THE TRAVELLER
}

\author{
S u m m a r y
}

One of Norwid's most significant acquaintances, already in the Warsaw period, and later in Paris, was the writer Edmund Chojecki (Charles Edmond). Their friendship started in Warsaw in the 1840s and lasted for a lifetime (at least until the 1870s), although its preserved epistolary traces are scarce. This sketch focuses on Chojecki's travelling reports and their inspiring influence on Norwid: Edmund's trip with Count Branicki to the Crimea (Wspomnienia z podróży po Krymie, Warszawa 1845), a journey to the North Seas with Prince Napoleon (Voyage dans les mers du Nord, Paris 1857), Chojecki's sojourn in Egypt at the turn of 1851, and finally his involvement in the setting up of the Egyptian exhibition (as the commissioner general) at the 1867 World Exhibition in Paris (L'Égypte à l'Exposition universelle de 1867, Paris 1867). The most important outcome of this inspiration is Norwid's drama Kleopatra i Cezar and his collection of Egyptian drawings in the album Orbis (I).

Key words: Cyprian Norwid; Edmund Chojecki (Charles Edmond); travels of the Romantics, Norwid's friendships; Kleopatra i Cezar; World Exhibition in Paris in 1867; the Orient of the Romantics.

RENATA GADAMSKA-SERAFIN - doktor nauk humanistycznych, Wydział Polonistyki Uniwersytetu Jagiellońskiego. Adres do korespondencji: Wydział Polonistyki UJ, ul. Gołębia 16, 31-007 Kraków, e-mail: renia5555@wp.pl. Autorka kilkudziesięciu publikacji z zakresu literatury i kultury polskiego romantyzmu, m.in.: Człowiek w myśli i twórczości C. K. Norwida (Sanok 2011); „Promethidion” Norwida i „List Ojca św. do artystów” w epoce upadku piękna; Norwidowskie arabica/islamica; ,"Ten sam jest Bóg” Norwid - Abd el-Kader - Ibn 'Arabi; ,Lud Koranu - Lud Ewangelii”. Norwid o historii relacji chrześcijańsko-muzulmańskich; Norwidowskie „etruski” literackie; „Kosmiczny patriotyzm-kapustykwaśnej” i „jajecznica narodowa”, czyli kulinaria w dyskursie Norwidowskim; Ślady Hafiza w „Assuncie” Norwida; „Pamięć serca”. „Król-Duch” i kwestia Armenii; Norwid-polski Hafiz?; Abd el-Kader o Europie XIX-wiecznej; Norwid i Turcja; Choroba, lekarze i medycyna w listach Juliusza Stowackiego etc. Publikuje na łamach „Ruchu Literackiego”, „Tematów i Kontekstów”, „Studiów Norwidianów”. Głównym przedmiotem badań autorki są wątki orientalne (zwłaszcza bliskowschodnie) w literaturze polskiego romantyzmu, a także twórczość polskich zesłańców kaukaskich. 